\title{
Megafaunal distribution and biodiversity in a heterogeneous landscape: the iceberg-scoured Rockall Bank, NE Atlantic
}

\author{
Katleen Robert ${ }^{1, *}$, Daniel O. B. Jones ${ }^{2}$, Veerle A. I. Huvenne ${ }^{2}$ \\ ${ }^{1}$ School of Ocean and Earth Science, University of Southampton, Waterfront Campus, European Way, \\ Southampton SO14 3ZH, UK \\ ${ }^{2}$ National Oceanography Centre, European Way, Southampton SO14 3ZH, UK
}

\begin{abstract}
Species distributions are influenced by spatial structure in environmental factors, but the scales at which these dependencies occur and the effect of habitat patch diversity, connectivity and spatial arrangement have rarely been investigated in deep-sea settings. In this study, spatially limited photographic transects collected from Rockall Bank, NE Atlantic, were combined with sidescan and multibeam sonar maps to model spatial patterns in species distribution and biodiversity. Sediment interpretation maps were created and canonical ordination techniques were used to examine relationships between fine-scale sediment characteristics extracted from the digital stills as well as landscape metrics describing the patch mosaic structure of the surrounding areas. Fine-scale sediment characteristics explained 45.1 and $63.8 \%$ of the variation in species composition and biodiversity, respectively. This survey effectively captured variation in species distribution resulting from iceberg ploughmarks, occurring at a scale of $<50 \mathrm{~m}$ - which would normally go undetected by traditional ship-based studies. Our study suggests that fine-scale environmental information is required to capture the spatial heterogeneity of complex seafloor areas in sufficient detail to model species distributions and biodiversity.
\end{abstract}

KEY WORDS: Landscape ecology $\cdot$ Deep sea $\cdot$ Megabenthic invertebrates $\cdot$ Spatial heterogeneity Biodiversity

\section{INTRODUCTION}

Long-term stability in the deep sea was initially suggested as an explanation for observed species richness that was higher than expected (Sanders 1968). However, the importance of spatial heterogeneity (the uneven distribution of environmental variables over space) was soon recognized (Jumars 1976). In a heterogeneous environment, a higher number of niches are available - which allows resource partitioning to occur, thereby reducing competitive exclusion between species (Williams 1964). The hypothesis that increased spatial heterogeneity leads to higher species richness has been examined in terrestrial (Pickett \& Cadenasso 1995, Tews et al. 2004) and shallow water environments (Hewitt et al. 2005, Mellin et

\footnotetext{
${ }^{*}$ Corresponding author: kr2e11@soton.ac.uk
}

al. 2012), but for many deep-sea areas, spatial heterogeneity has not yet been mapped at sufficient resolution to represent fine-scale biodiversity patterns over large spatial extents (Thrush et al. 2008, Levin \& Sibuet 2012). Yet this information would confer a significant advantage for the implementation of management measures, where precautionary decisions may have to be made based on limited evidence. In this case, seafloor heterogeneity, which can be rapidly described via acoustic surveys, could be employed as a proxy for biological diversity or conservation priority, reducing the significant time investment associated with biological data collection, identification and manual quantification (Schoening et al. 2012).

Spatial patterns in species distribution can arise from interactions between organisms (e.g. intraspeci-

(C) The authors 2014. Open Access under Creative Commons by Attribution Licence. Use, distribution and reproduction are unrestricted. Authors and original publication must be credited. 
fic: reproduction or recruitment; and interspecific: predation or competition) or be induced by spatial structures exhibited by environmental factors (Legendre 1993). Characterizing the relationships between environmental factors and species distributions is a first step in accurately predicting species distributions and creating fine-scale habitat maps. Environmental variables vary over different spatial scales to form a mosaic of interspersed habitat patches on the seafloor (Jumars 1976). However, in the deep sea the scales at which these factors influence species distributions have not yet been thoroughly investigated. At broader spatial scales (i.e. 100 to $1000 \mathrm{~km}$ ), deep-sea studies on the relationships between environmental variables and biodiversity have showed that water mass and current-related factors (e.g. oxygen and temperature), as well as flux of organic material have the strongest influence on biodiversity (Levin et al. 2001, Sellanes et al. 2010, Williams et al. 2010). At medium scales (i.e. 1 to $10 \mathrm{~s}$ of $\mathrm{km}$ ), the presence of large geomorphological features such as submarine canyons, nodule fields or habitat forming biological structures are significant (Henry \& Roberts 2007, Sellanes et al. 2010, Vetter et al. 2010). The importance of sediment properties (e.g. hardness, grain size), food resources (e.g. organic matter content) and disturbance rate appears only at finer spatial scales (i.e. $\mathrm{m}$ to $\mathrm{km}$ ) (Vetter \& Dayton 1999, Gutt \& Piepenburg 2003, McClain \& Barry 2010).

The spatial relationships between habitat patches and their effects on the distribution and composition of the deep-sea benthic fauna has even more rarely been examined (Wedding et al. 2011). The field of 'landscape ecology', developed in terrestrial environments, has focused on creating metrics to describe the geometry and spatial arrangement of habitat patches and their relationships to ecological processes (Turner \& Gardner 1991). Class metrics are used to describe properties of patches from a single substratum type, while landscape metrics consider all patches present within a landscape (McGarigal et al. 2012). In shallow marine environments, a landscape approach has been used to examine the effects of habitat fragmentation in seagrass beds (Jackson et al. 2006), the importance of patch size and connectivity in coral reefs (Grober-Dunsmore et al. 2007), spatial patterns in rocky benthic species assemblages (Garrabou et al. 1998) as well as the multi-scale influence of landscape structure on the spatial distribution of fish species (Pittman et al. 2004, Monk et al. 2011). Metrics such has fractal dimension have also been found useful in describing irregular shapes such as spatial patterns within mussel beds (Com- mito \& Rusignuolo 2000) and the morphology of marine branching sessile organisms (Kaandorp 1999). Although application of spatial metrics in deeper marine ecosystems had been limited owing to difficulties associated with underwater mapping, it was successful in explaining fine-scale $(<1 \mathrm{~m})$ benthic species assemblages in the Antarctic (Teixidó et al. 2002, Teixidó et al. 2007). In deeper sites, the landscape is often characterized by sediment type, and not by vegetation or biogenic structures (with the exception of cold-water corals, carbonate mounds and sponge aggregations (Klitgaard 1995, Howell et al. 2011), resulting in more subtle changes in seafloor structure which makes it inherently difficult to delineate benthic habitats (Zajac 2008). However, recent studies in automated seabed classification based on sidescan or multibeam sonar backscatter have greatly facilitated the creation of high resolution sediment interpretation maps (Wilson et al. 2007, Lucieer 2008, Brown et al. 2012). Analysis of these maps from a landscape perspective has the potential to increase the amount of ecologically meaningful information extracted. Since no additional data collection is required, this approach has the potential to reduce the time needed to gather sufficient information to address management issues.

As the anthropogenic footprint of activities such as trawling extends deeper into our oceans, detailed descriptions of seafloor habitats and the species they harbour become increasingly important in order to establish the baseline state of this ecosystem (Levin \& Sibuet 2012). As the environmental variables responsible for spatial structuring in species distribution vary over different scales, choice of resolution and spatial extent will affect the ecological processes that can be examined (Levin 1992). We must find sampling resolutions that retain enough fine-scale variation to describe species distributions while remaining coarse enough to be economically feasible (Przeslawski et al. 2011).

This study used a hierarchical survey to examine a highly heterogeneous seafloor area characterized by iceberg ploughmarks on Rockall Bank, NE Atlantic (200 to $400 \mathrm{~m}$ depth). A fine-scale analysis of photographic transects was first carried out to identify megafaunal species and map their distribution and biodiversity. A landscape approach was then used to examine whether the inclusion of metrics describing the spatial arrangement of habitat patches could improve the explanatory power of models using environmental variables to describe species composition and distributions. The amount of variation explained by survey techniques of varying resolutions was also 


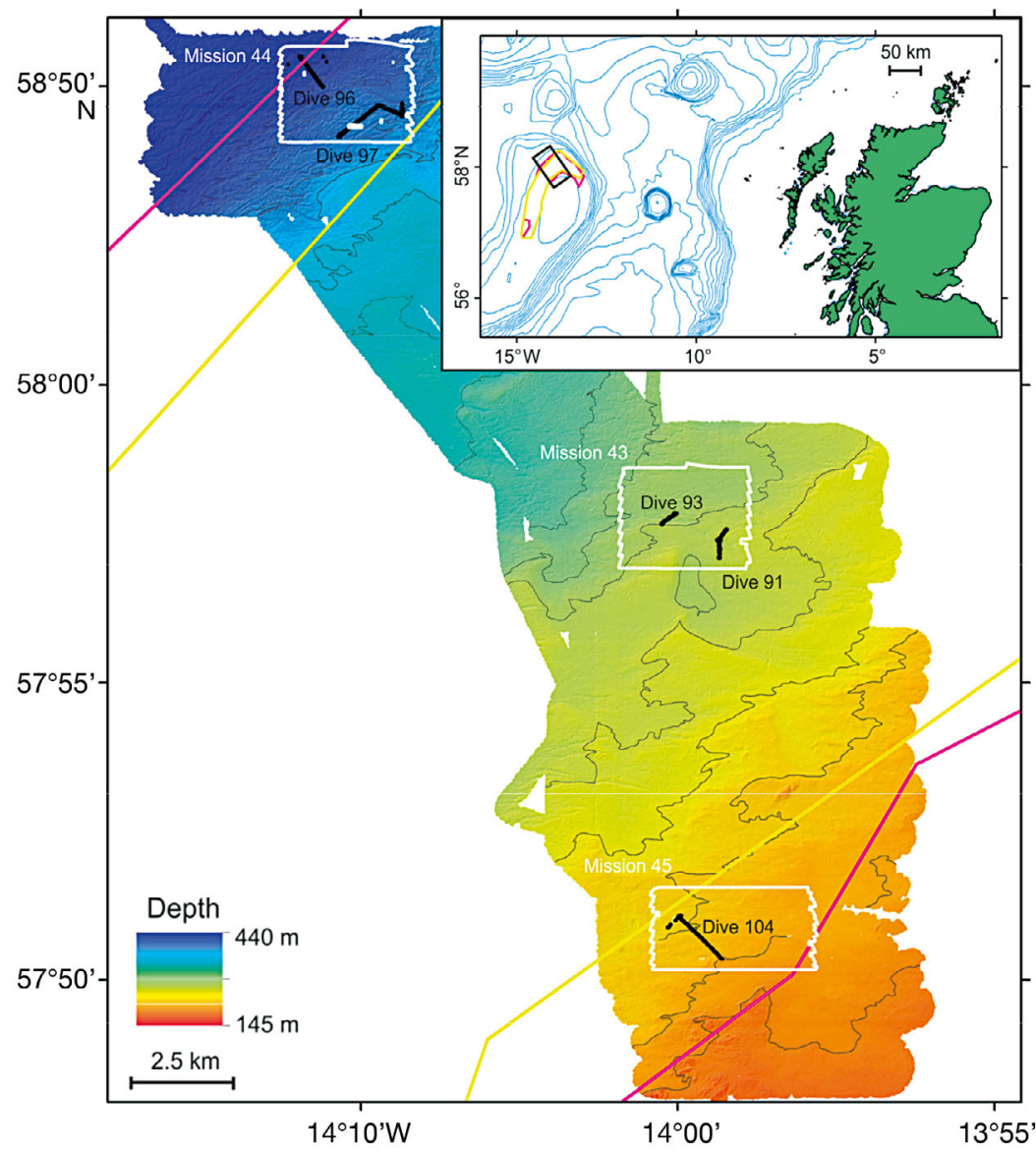

Fig. 1. Hierarchical survey carried out on Rockall Bank, Northeast Atlantic. Ship-based bathymetry displayed with superimposed outlines of the sidescan sonar data (white) collected during 3 autonomous underwater vehicle (AUV) missions. The 5 remotely operated vehicle (ROV) imagery transects are shown in black. Insert shows the position of Rockall Bank in relation to Scotland; the black rectangle represents the location of the survey. The boundaries of the 2007 Fisheries Closure area and candidate for 'Special Area of Conservation' are illustrated in yellow and pink, respectively. Background bathymetry of the Northeast Atlantic from GEBCO (General Bathymetric Chart of the Oceans; IOC IHO and BODC 2003)

examined, and the scale of variation in the biological data was used to identify the process potentially responsible for the spatial structure captured by the survey.

\section{MATERIALS AND METHODS}

\section{Study site}

Rockall Bank, NE Atlantic (Fig. 1) is a shallower part of the larger Rockall Plateau, a subsided and submerged microcontinent which includes HattonRockall Basin and Hatton Bank to the northwest, and which is separated from the Scottish continental mar- gin by Rockall Trough (Roberts 1971, 1975). The seabed of the Rockall Bank has a long history of investigation (Thomson 1874). The shallower areas of the western bank have a heterogeneous seabed, including partly buried rock outcrops, boulder and cobble fields as well as large areas of carbonate sand cover (Roberts 1975). The deeper western and southern flanks (250 to $450 \mathrm{~m}$ water depth) are incised with deep scours $(<8 \mathrm{~m})$ from iceberg keels having ploughed the seabed during periods of Quaternary low sea levels (Sacchetti et al. 2012). Over time, soft sediment filled the centre of the ploughmarks while coarse debris remained at the scar edges. The presence of dispersed hard substratum has allowed colonization by the cold-water coral Lophelia pertusa (Wilson 1979a,b, Rogers 1999). A high diversity of organisms has been reported associated with $L$. pertusa patches (Jensen \& Frederiksen 1992, Wienberg et al. 2008) but there has been little investigation of the fauna of the softer sediments (Wilson \& Desmond 1986). In 2007, the North East Atlantic Fisheries Commission established a Fisheries Closure on the northwestern flank of Rockall Bank. In 2010, a nearly overlapping area was proposed by the Joint Nature and Conservation Committee (JNCC), an adviser group to the UK Government, as a candidate 'Special Area of Conservation' (SAC) under the EU Habitats Directive, with the aim to protect the cold-water coral communities from extensive deep-water fishing activities (Howell et al. 2009, JNCC 2010a)

\section{Survey design and data collection}

Map creation

A nested seafloor survey of the northwestern flank of Rockall Bank (Fig. 1) (200 to $400 \mathrm{~m}$ depth) was carried out during the RRS 'James Cook' 060 cruise in May and June 2011 as part of the 'Marine Environmental Mapping Programme' (MAREMAP: www.maremap.ac.uk/index.html) and the 'COmplex Deep-sea Environments: Mapping habitat heterogeneity As Proxy for biodiversity' project (CODEMAP: www.codemap.eu/). Three missions (M43, M44 and 

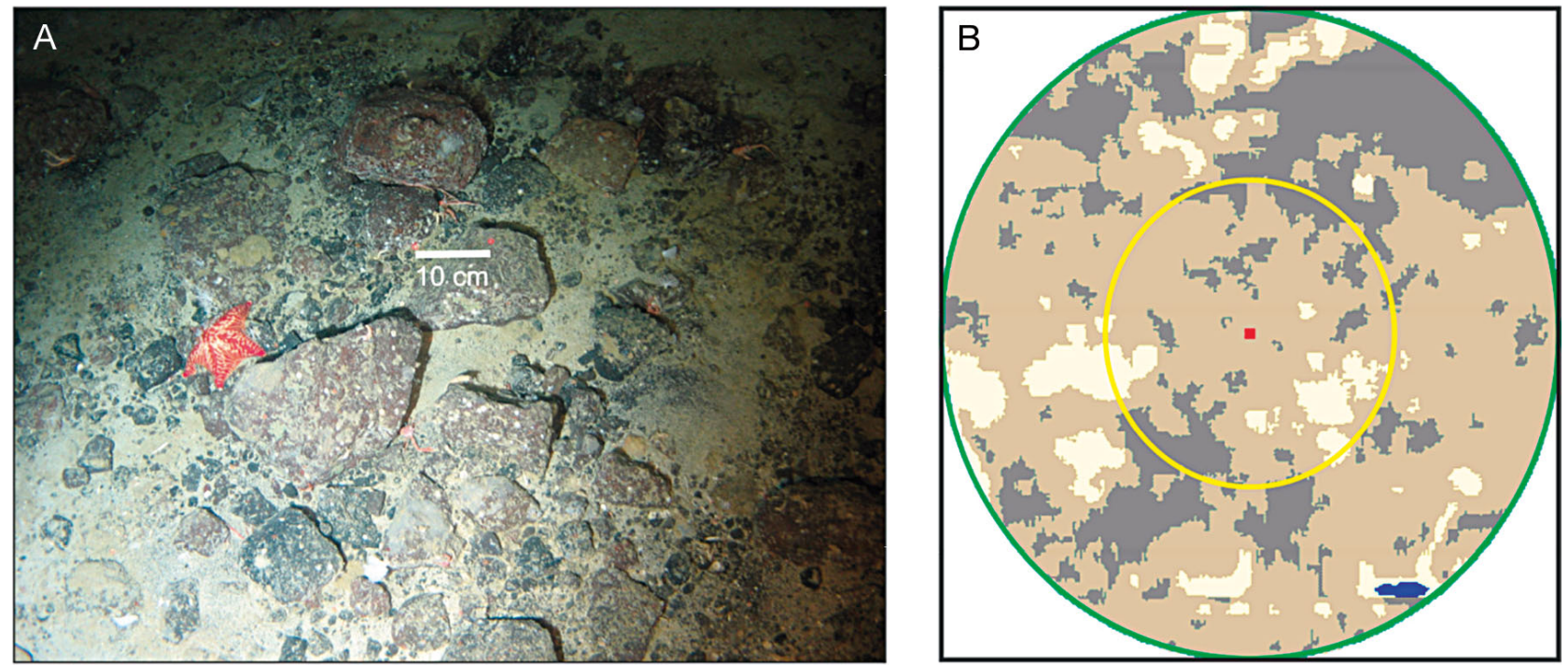

Fig. 2. (A) Image acquired via remotely operated vehicle illustrating megabenthic organisms and a mixed substratum. Laser beams are separated by $10 \mathrm{~cm}$. (B) Associated circular areas (green and yellow; $75 \mathrm{~m}$ and $30 \mathrm{~m}$ radii) as represented by the sediment interpretation map. Soft, mixed and hard substratum types are represented in grey, tan and cream, respectively, while coral stand are shown in blue. The red square illustrates the approximate area covered by the image

M45) by the autonomous underwater vehicle (AUV) Autosub6000 were carried out, mapping 3 distinct areas of seafloor $\left(12.0,12.0\right.$ and $13.0 \mathrm{~km}^{2}$, respectively) using an EdgeTech high frequency $(410 \mathrm{kHz})$ high-resolution (resulting pixel size of $0.5 \times 0.5 \mathrm{~m}$ ) sidescan sonar. These were located in areas within (M43) and immediately outside (M44 and M45) the Fisheries Closure, but still within the candidate SAC (Fig. 1). Ship-board bathymetry of the surrounding area $\left(380 \mathrm{~km}^{2}\right)$ was also collected using a Kongsberg EM710 mutibeam echosounder (128 beams; resulting pixel size of $20 \times 20 \mathrm{~m}$ ).

Thematic maps representing seafloor substratum composition were produced, based on an unsupervised classification of the sidescan sonar backscatter. Unsupervised classification attempts to identify structure within the data and segment it into units without prior recourse to in situ reference points (Brown et al. 2012). This classification used mean backscatter, average grey level difference, and variance within a $9 \times 9$ pixel moving window to assign each pixel to 1 of 6 classes: soft, mixed or hard substratum, coral stand or rubble, and exposed bedrock. Mean backscatter represented substratum hardness while variance at fine spatial scales was indicative of more complex substratum structures such as coral stands, where strong contrasts occur between the high backscatter of the corals in combination with the low backscatter caused by their shadows (Huvenne et al. 2002). Sediment patches of less than 12 pixels were filtered out; those pixels were assigned to the sediment class represented by the majority of neighbouring pixels.

\section{Biological imagery}

Within the areas surveyed by the AUV, 5 remotely operated vehicle (ROV) photographic transects (Stns 91, 93, 96, 97 and 104) were conducted using a SAAB SeaEye Lynx. Digital stills (Fig. 2) were taken every $\sim 40 \mathrm{~s}$ using an oblique mounted downwardlooking Kongsberg OE14-208 camera (focal length: $7.188 \mathrm{~mm}$ and maximum aperture: f/2) equipped with parallel lasers for scale (10 $\mathrm{cm}$ separation), and used for analysis of megabenthic invertebrates. Using the image processing software Image J (http:// rsbweb.nih.gov/ij/), all images from a transect were imported using the 'Image Sequence' function to form a 'stack' (multiple images displayed consecutively in a single window); each organism was identified, marked and its pixel position recorded to avoid risks of double counting. Images of suboptimal quality were removed as well as those collected when ROV altitude varied beyond the 1 to $2.25 \mathrm{~m}$ range. Each image was then georeferenced using the ROV's ultra-short baseline (USBL) navigation system which also recorded its depth and altitude. The ROV position was estimated based on a moving average of the navigation with a 4-reading subset, correspon- 
ding to $1 \mathrm{~s}$. See Table 5 for average depth, transect lengths and number of images collected per transect. The ROV was also equipped with a SeaKing CTD which showed average bottom temperatures of $9.26^{\circ} \mathrm{C}\left(\mathrm{SD}=0.10^{\circ} \mathrm{C}\right)$ and salinities of $34.8 \%$ o $(\mathrm{SD}=$ $0.025 \%$ o).

When species-level identification would have required sample collection, visually distinctive taxa were identified to the lowest possible taxonomic unit and assigned to morphospecies. The use of morphospecies is somewhat problematic, as cryptic species will be considered under a single grouping while other groups showing greater morphological variation (e.g. sponges) may be split into more groups, but their use is common in marine studies where imagery is used as the main sampling tool (Soltwedel et al. 2009, Schlacher et al. 2010, Compton et al. 2013). Although the use of higher taxonomic levels is another option to estimate biodiversity (Roy et al. 1996), these tend to be more useful when investigating broader scale patterns-and in the case of our dataset, even family-level identification of sponges is problematic without specimen collection. As such, the diversity measures presented are likely underestimated, but represent the closest estimates that can be achieved. Consultation with the image catalogue compiled by Howell \& Davies (2010) for morphospecies encountered in the surrounding area was carried out, and a set of voucher images was assembled. This set of images was deposited in the publicly available SERPENT media archive (http://archive. serpentproject.com/). In the case of encrusting species, individual colonies were counted. For community analysis, only morphospecies for which at least 10 individuals were observed and a presence recorded in at least 10 images were retained, but every record was retained for biodiversity calculations (Shannon index of diversity, $H^{\prime}$, Shannon 1948). To examine the effect that cryptic species may have on estimates of biodiversity, a percentage $15 \%$ and $20 \%$ ) of the number of taxa listed in OBIS (Ocean Biogeographic Information System, www.iobis.org/) for the North Atlantic Ocean was used as a potential number of present, but undistinguishable cryptic species. When 2 or more specimens of a morphospecies of ascidians, bryozoans, cerianthids, cormatulids, sponges, ophiuroids, sabellid worms or sipuncula worms were observed within an image, each individual was randomly assigned, with replacement, to a potential cryptic species, and biodiversity estimates were recalculated. This analysis was conducted in order to determine whether the uncertainty created by the use of morphospecies was high enough to effect the conclusions of the study. However, as the trends observed did not change, we argue that the use of morphospecies is appropriate for this study (results presented in Supplement 1 at www.intres.com/articles/suppl/m501p067_supp.pdf).

Imagery-derived environmental variables

Composition of the substratum was visually assessed in each image based on grain size classes: soft sediment, gravel, pebbles (4 to $64 \mathrm{~mm}$ ), cobbles (64 to $256 \mathrm{~mm}$ ) and boulders (>256 mm) (Wentworth 1922). Pebbles of $4 \mathrm{~mm}$ could be measured in the imagery, but only a visual distinction in texture could be used to separate soft sediments from gravel. The overall composition was first assigned to 1 of 7 seabed facies: sand, sand and pebbles or gravel, sand and cobbles, cobble-dominated, coral stand, coral rubble and exposed bedrock (example images are provided in Supplement 2 at www.int-res.com/ articles/suppl/m501p067_supp.pdf). To obtain a quantitative description of substratum composition, percentage covers were obtained by importing images in the freely available statistical software $\mathrm{R}$ (R Development Core Team 2011) and drawing 100 randomly located points for each image. Using a custom-made $\mathrm{R}$ code with an interactive prompt, the substratum (grain size class, exposed bedrock, coral rubble or coral stand) at each location was recorded.

\section{Sonar-derived environmental variables}

The spatial structure (e.g. size, shape, composition, spatial arrangement and diversity) of the seafloor habitat patches represented in the sediment interpretation of the sidescan sonar maps (complete extent figures are available in Supplement 3 at www.intres.com/articles/suppl/m501p067_supp.pdf) was described using the class and landscape metrics listed in Table 1. Metrics were grouped into 5 general groups 'area and edge', 'shape', 'core area', diversity' (Peng et al. 2010, McGarigal et al. 2012). The first group is related to size of the patches and amount of edge, the second group is used to characterize the geometry of the different patches and the third grouping examines patch sizes when the edge cells (only the first one in this study) are removed. Spatial arrangement of patches to each other is described by the fourth group, while diversity measures (only available for landscape analysis) form the last group. Refer to McGarigal et al. (2012) for a thorough description of 
Table 1. Class and landscape level metrics considered in the analysis. Class metrics were calculated for each of the 6 substratum classes present in the sediment interpretation maps: soft, mixed or hard substratum, coral stand or rubble, and exposed bedrock. For formulas and descriptions see McGarigal et al. (2012)

Class metrics
Area and edge metrics
Patch number
Total area
Patch density
Edge length
Edge density
Mean patch area
Smallest patch area
Largest patch area
Shape metrics
Landscape shape index
Largest patch index
Perimeter area fractal dimension
Mean perimeter area ratios
Minimum perimeter area ratioa
Maximum perimeter area ratio
Mean shape index
Minimum shape index
Maximum shape index
Core area metrics
Total core area
Mean core area
Smallest core area
Largest core area
Aggregation metrics
Proportion of like adjacencies
Aggregation index
Landscape division index
Splitting index
Effective mesh size
Patch cohesion index

Landscape metrics

Area and edge metrics

Patch number

Patch density

Edge length

Mean patch area

Smallest patch area

Largest patch area

Shape metrics

Landscape shape index

Largest patch index

Mean shape index

Minimum shape index

Maximum shape index

Core area metrics

Total core area

Mean core area

Smallest core area

Largest core area

Mean core area index

Aggregation metrics

Proportion of like adjacencies

Aggregation index

Landscape division index

Splitting index

Effective mesh size

Patch cohesion index

Diversity metrics

Patch richness

tion partitioning (explained below) was used to select which 2 circle sizes provided the most appropriate metrics to describe the biological variation observed.

For each image, the statistical mean and variance in backscatter as obtained from the original sidescan sonar maps were calculated based on all pixels present within the 2 circular areas. Area-weighted averages for slope, curvature, aspect, surfacearea ratio and bathymetric position index (BPI) were calculated for the $4 \mathrm{~m}$ surrounding the position of each image. The layers were derived from a $20 \times 20 \mathrm{~m}$ resolution base surface of the multibeam data (spatial reference: World Geodetic System '84 Universal Transverse Mercator Zone 28N). As BPI varies depending on neighbourhood size, 2 layers were created: coarse and fine, based on 10 pixels and 2 pixels neighbourhood radii (Wilson et al. 2007). Layers were generated in ArcGIS using the 'Spatial Analyst Extension' as well as the 'Land Facet Corridor Tools' and 'DEM Surface Tools' developed by Jenness Enterprises (Jenness 2012a,b).

\section{Statistical analysis}

Owing to the number of statistical methods employed, only a general description is provided below; additional details are provided in Supplement 4 at www.int-res.com/ articles/suppl/m501p067_supp.pdf. Analy-

each measure and equations. In the present study, circular areas of seafloor $(1,5,10,20,30,40,50,75$ and $100 \mathrm{~m}$ in radius) were delimited around each image (Fig. 2). Within those circular areas, class and landscape metrics were computed using the 'SDMTools' (Species Distribution Modelling Tools) package in R. Compared with the seafloor visible in the finescale imagery, these class and landscape metrics provided a description of the broader seabed surrounding each image. The use of increasingly larger area sizes was carried out in order to determine which one would be most appropriate for the calculation of class and landscape metrics as explanatory variables for species composition and biodiversity. Using the statistical techniques described below (redundancy analysis or linear regression with forward selection), metrics were selected for each circle size, and the amount of variation explained was calculated. Varia- ses were carried out in the statistical software R using the libraries 'vegan', 'labdsv' and 'gstat'. A methodological flowchart is also presented (Fig. 3) with each major step (as described below) represented by numbers (1 through 9). An extensive review of statistical techniques for spatial analysis of community data, including the ones employed in this study, is available in Dray et al. (2012).

\section{Environmental variable selection}

To determine which explanatory variables (e.g. sediment percentage cover, class and landscape metrics, and multibeam sonar-derived layers) could best explain morphospecies distribution, (1) redundancy analysis (RDA) was used. RDA is a type of constrained ordination which allows the regression 


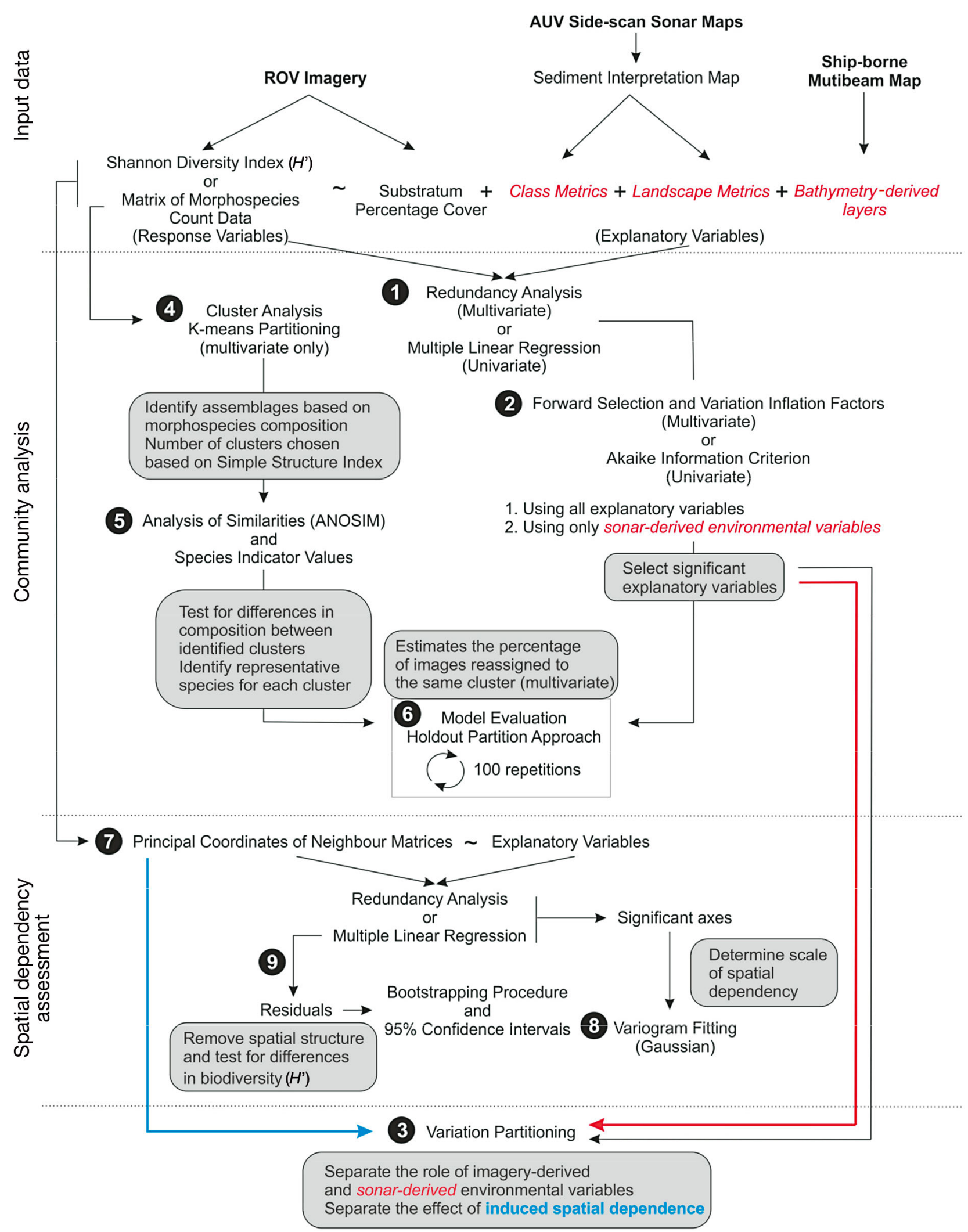

Fig. 3. Methodological flow chart representing the statistical analysis. Rounded rectangles contain short descriptions of the aims of specific steps. Elements in red show the steps involved for sonar-derived environmental variables while elements in blue show the steps involved to separate the effect of induced spatial dependence 
concept to be applied to a multivariate response variable (such as a species matrix) (Legendre \& Legendre 1998). The morphospecies abundance matrix was $\log _{10}(x+1)$ transformed before the analysis to reduce the influence of abundant species (Clarke \& Warwick 2001). (2) Forward selection was carried out to obtain the most parsimonious model and variance inflation factors (VIF) were used to exclude additional explanatory variables that showed strong collinearity with others present within the model (Borcard et al. 2011). To compare the information obtained from sampling tools of differing resolution (ROV images: $<1 \mathrm{~m}$, versus acoustic maps: 1 to $20 \mathrm{~m}$ ), this step was carried out once using all explanatory variables and once using only sonar-derived environmental variables. As only lower resolution survey methods are generally available over large extents, (3) variation partitioning (Peres-Neto et al. 2006) was used to examine the amount of variation that was no longer captured when imagery-derived environmental variables (e.g. sediment percentage cover) were no longer available. The amount of variation in species composition and biodiversity explained by the sediment class present at the location of the image and the values of the multibeam-derived layers was also calculated. This determined whether the inclusion of landscape metrics increased explanatory power when compared to the use of sediment interpretation maps as abiotic proxies for species assemblages. These steps were also carried out using the Shannon index of diversity $\left(H^{\prime}\right)$ (Shannon 1948) as a response variable, but linear regression was used instead of RDA as the response variable was now univariate.

\section{Species assemblages}

To identify clusters of images of similar morphospecies composition, (4) K-means partitioning was employed. This method aims at separating observations into a predefined number of clusters by minimizing the distance between individual samples and the center of their assigned cluster (Hartigan \& Wong 1979). The optimal number of cluster was selected using the 'simple structure index' (Dimitriadou et al. 2002). (5) ANOSIM was used to assess significant differences in morphospecies composition between clusters and representative species for each cluster were identified based on 'species indicator values' (Dufrene \& Legendre 1997).

\section{Model evaluation}

As an additional independent dataset was not available, (6) model evaluation was carried out using a 'holdout partition' approach. A subset of the data (300 randomly selected images) was removed from the original dataset and the RDA parameters were recomputed. The removed data points were then reclassified, and the percentage of data points reassigned the same cluster was calculated. This process was repeated 100 times to estimate variability in the results obtained. Marine benthic studies employing similar methodological approaches include Hewitt et al. (2004), Teixidó et al. (2007) and Verfaillie et al. (2009)

\section{Spatial dependency assessment}

To determine how much of the spatial structure present in the species dataset can be explained by spatial structuring of environmental variables (induced spatial dependence), (7) principal coordinates of neighbour matrices (PCNM) were used (Borcard \& Legendre 2002, Dray et al. 2006). This approach yielded synthetic representations of potential spatial structures based on distances between sampling sites. These synthetic representations were then compared to the spatial structure present in the species dataset, and those found to be accurate representations were included in the variation partitioning Step (3) to assess how well the environmental variables described the biological spatial structures modelled. (8) Gaussian variogram creation of the selected spatial representations was used to determine the scale of variation captured (the distance required for 2 points to be considered independent). As PCNM represent the spatial structure present within the species dataset, they can also be used to alleviate issues associated with autocorrelation. This property was used to compare differences in biodiversity at a broader scale, between transects and substratum facies.

\section{Broader-scale spatial patterns}

In order to assess broader-scale patterns, class and landscape metrics were calculated within a $200 \mathrm{~m}$ buffer around each transect line. Linear regressions of diversity, organism abundance and substratum percentage cover observed in each image were carried out against depth. To examine differences in 
biodiversity (between transects and between seabed facies), we first accounted for spatial autocorrelation by filtering out the spatial structure previously modelled (9). The biodiversity indices were first regressed against the significant PCNMs, and the residuals were used as response variables in the analysis. Because transects length differed, data resampling with replacement was carried out to obtain 75 images from each transect. The 95\% confidence intervals around the mean residual biodiversity for each transect were built using a bootstrapping procedure with 999 repetitions. For the seabed facies, the same bootstrapping procedure was applied, but sample size was standardized to 30 images.

\section{RESULTS}

In the 1222 images analysed, a total of 7267 individual organisms were observed from 81 morphospecies (for a complete list see Supplement 5 at www.int-res.com/articles/suppl/m501p067_supp.pdf). Many of these were rare, and only 35 morphospecies were seen in more than 10 images (Fig. 4). The squat lobster Munida sarsi made up the largest percentage $(33.0 \%)$ of the organisms observed and was the dominant species in all transects with the exception of Transect 96, which was dominated by the holothurian Parastichopus tremulus ( $40.3 \%$ of fauna). However, across all transects, $P$. tremulus only represented $2.6 \%$ of the total observations. Only the bryozoan Reteporella sp. (13.1\%) and colonies of yellow $(9.8 \%)$ and white $(6.2 \%)$ encrusting sponges composed more than $5 \%$ of the total observations.

The class and landscape metrics calculated at varying scales showed that the most variation was captured using a radius of $40 \mathrm{~m}$ for both morphospecies composition and biodiversity. However, when 2 circle sizes were considered, the highest variation explained was achieved using metrics derived from areas with radii of $30 \mathrm{~m}$ and $75 \mathrm{~m}$ for morphospecies composition, and $20 \mathrm{~m}$ and $75 \mathrm{~m}$ for biodiversity (results included in Supplement 6 at www.int-res. com/articles/suppl/m501p067_supp.pdf). For simplicity, sonar-derived metrics calculated at $30 \mathrm{~m}$ and $75 \mathrm{~m}$ were used for the analysis.

Following forward selection, a large number of environmental variables (substratum percentage cover, class and landscape metrics as well as backscatter and bathymetric variables) significantly explained morphospecies composition and biodiversity (Tables 2 \& 3). The most parsimonious models including all environmental variables explained $45.1 \%$ $(p=0.001)$ and $63.8 \%(p<0.001)$ of the variation for morphospecies composition and biodiversity, respectively. When models relied solely on sonar-derived environmental characteristics, lower percentages of variation were explained: $24.7 \%(p=0.001)$ and $40.6 \%(\mathrm{p}<0.001)$ for morphospecies composition and biodiversity, respectively. However, these percentages were much higher than what was obtained when only the sediment interpretation class and multibeam-derived information were employed: variation explained $13.0 \%(\mathrm{p}=0.001)$ for morphospecies composition and $22.9 \%(\mathrm{p}<0.001)$ for biodiversity.

The first 14 axes of the redundancy analysis were significant, but only the first 2 axes are illustrated in the ordination graphs. Substratum percentage cover, as obtained from the imagery, best explained variation in the morphospecies count data (Fig. 5A). The first canonical axis illustrates a gradient in images dominated by soft to hard substrata, while the second axis represents the presence of coral rubble and stands. The vectors representing species scores (Fig. 5B) separate into 3 subgroups: upper right quadrant, characterized by squat lobsters Munida sarsi, a species of Actiniaria, yellow encrusting sponges and Sabellid worms; lower right quadrant, showing predominance of other small encrusting sponge colonies and bryozoan species as well as the asteroid Porania pulvillus; and lower left quadrant, represented by the holothurian Parastichopus tremulus. K-means partitioning showed a similar trend by identifying an optimum of 3 clusters. However, the use of 4 clusters allowed the separation of species occurring on both corals and hard substratum from those more closely associated with live coral stands. As the 4 clusters differed significantly in their morphospecies composition based on ANOSIM analysis $(R=0.85, p=0.001)$, they were retained.

Between 3 and 15 morphospecies were representative for each cluster, as determined by indicator species analysis (Table 4). However, no morphospecies significantly represented the cluster associated with soft sediment habitats, although this is likely a result of the low densities of organisms observed in this habitat. There was a clear separation in ordination space of images assigned to each K-means cluster (Fig. 6). At the transect level, morphospecies associated with soft sediments only represented $5.3 \%$ of total organisms observed, while coral-associated morphospecies represented $18.9 \%$. The remainder of the organisms recorded represented hard bottom $(40.1 \%)$ or more generalist morphospecies (e.g. associated with hard substratum, coral stand and rubble; 

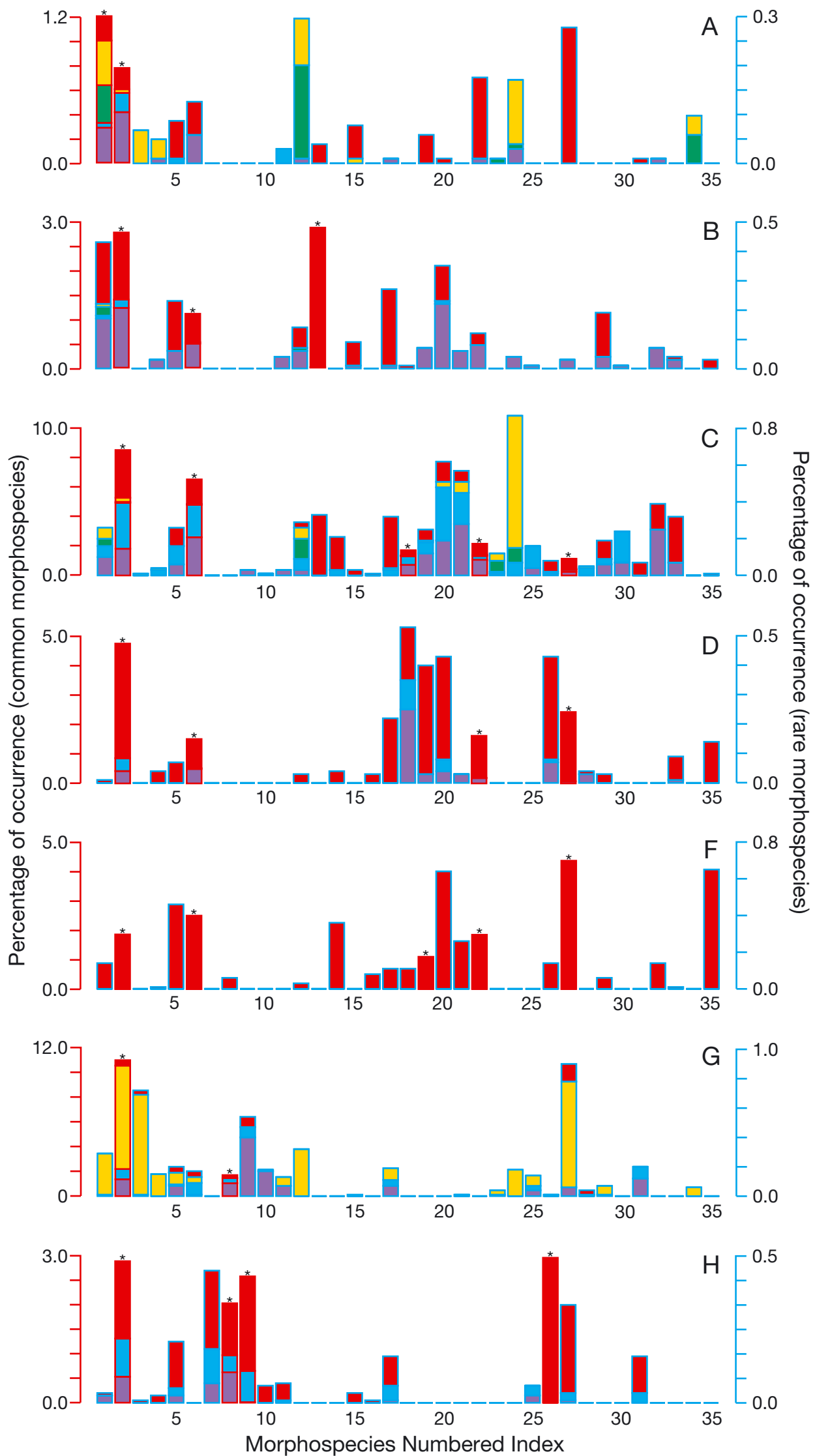

Transect 91

Transect 93

Transect 96

Transect 97

Transect 104

Fig. 4. Percent occurrence (total no. of inds. counted for a given species / total no. of ind. organisms observed $\times 100$ ) for each of the 35 morphospecies retained for the community analysis. Values are colour-coded by transect and separated by seabed facies: (A) sand, (B) sand and pebbles or gravel, (C) sand and cobbles, (D) cobble dominated, $(E)$ bedrock, $(F)$ coral rubble, and (G) coral stands. Two scales were used in order to improve visualization: bars with red outlines marked with asterisks show the more common morphospecies, while bars with blue outlines are associated with the scale on the right and represent rarer morphospecies. Morphospecies numbers refer to the list presented in Table 4 
Table 2. Selected environmental variables for the most parsimonious models (with and without including fine-scale imageryderived information) for the morphospecies count matrix. $\alpha=$ class metrics, $\beta=$ landscape metrics, $\gamma=$ sidescan sonar, $\delta=$ multibeam sonar, $\varepsilon=$ ROV imagery-derived variables

\begin{tabular}{|c|c|c|}
\hline & Sonar & Imagery and sonar \\
\hline $\begin{array}{l}\text { Explanatory } \\
\text { variables }\end{array}$ & $\begin{array}{l}\beta \text { Number of patches }(75 \mathrm{~m}) \\
\alpha \text { Proportion of like adjacencies sand }(30 \mathrm{~m}) \\
\alpha \text { Total area coral }(30 \mathrm{~m}) \\
\gamma \text { Mean backscatter }(30 \mathrm{~m}) \\
\alpha \text { Mean shape index coral }(75 \mathrm{~m}) \\
\alpha \text { Effective mesh size bedrock }(30 \mathrm{~m}) \\
\delta \text { Aspect } \\
\beta \text { Mean shape index }(75 \mathrm{~m}) \\
\alpha \text { Minimum patch core area coral }(30 \mathrm{~m}) \\
\alpha \text { Patch density bedrock }(30 \mathrm{~m}) \\
\alpha \text { Patch density rubble }(30 \mathrm{~m}) \\
\alpha \text { Landscape shape index mixed }(30 \mathrm{~m}) \\
\beta \text { Largest patch index }(30 \mathrm{~m}) \\
\alpha \text { Proportion of like adjacencies sand }(75 \mathrm{~m}) \\
\alpha \text { Largest patch index coral }(75 \mathrm{~m}) \\
\alpha \text { Mean shape index bedrock }(30 \mathrm{~m}) \\
\alpha \text { Minimum patch area bedrock }(75 \mathrm{~m}) \\
\beta \text { Mean core area index }(75 \mathrm{~m}) \\
\alpha \text { Mean shape index mixed }(75 \mathrm{~m}) \\
\alpha \text { Mean patch core area hard }(75 \mathrm{~m}) \\
\alpha \text { Maximum shape index sand }(75 \mathrm{~m}) \\
\gamma \text { Mean backscatter }(75 \mathrm{~m}) \\
\beta \text { Maximum shape index }(30 \mathrm{~m}) \\
\alpha \text { Landscape shape index sand }(30 \mathrm{~m}) \\
\gamma \text { Variance backscatter }(75 \mathrm{~m}) \\
\alpha \text { Minimum shape index sand }(75 \mathrm{~m}) \\
\alpha \text { Mean patch area sand }(75 \mathrm{~m}) \\
\alpha \text { Mean patch core area mixed }(30 \mathrm{~m}) \\
\alpha \text { Mean shape index hard }(30 \mathrm{~m}) \\
\alpha \text { Minimum patch core area rubble }(75 \mathrm{~m}) \\
\end{array}$ & 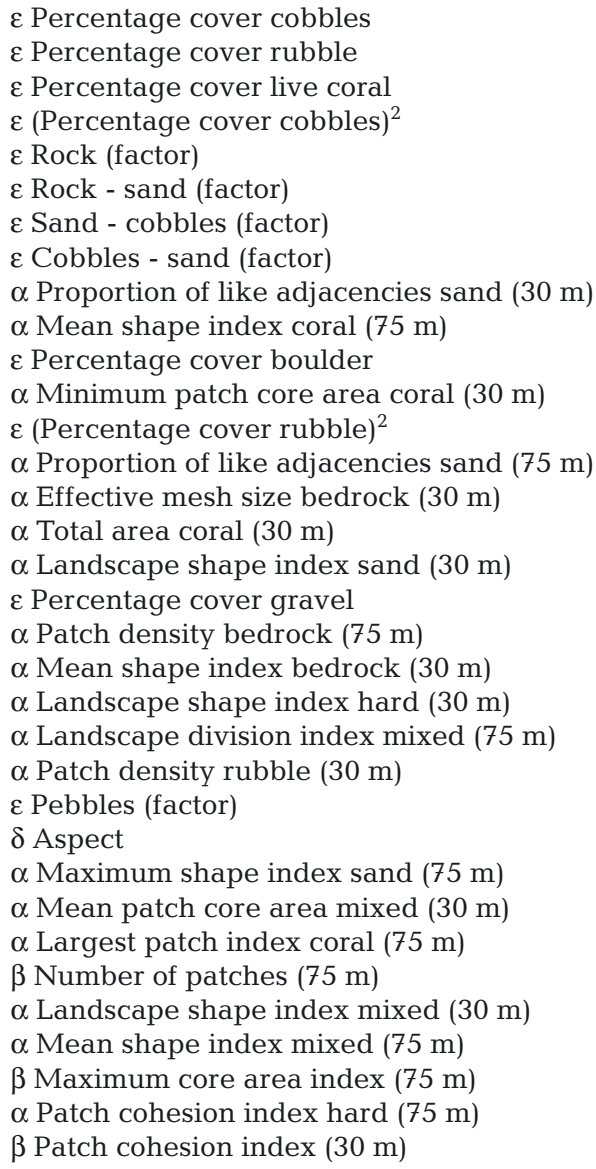 \\
\hline $\begin{array}{l}\text { Adjusted } R^{2} \\
\text { F-value } \\
\text { p-value }\end{array}$ & $\begin{array}{l}24.7 \% \\
12.1, d f=36,1185 \\
0.001\end{array}$ & $\begin{array}{l}45.1 \% \\
26.1, d f=40,1181 \\
0.001\end{array}$ \\
\hline
\end{tabular}

$38.3 \%$ ). High percentages of hard bottom-associated morphospecies were recorded for Transects 91 $(49.0 \%)$ and 104 (46.9\%). Organisms representing morphospecies associated with corals ranged between 16.7 and $18.9 \%$ of the observations for Transects 91, 93 and 104, but fell below 5\% for Transects 96 and 97. Morphospecies associated with soft sediments represented $54.5 \%$ and $14.2 \%$ of total observations for Transect 96 and 97, respectively, but less than $5 \%$ in the remaining transects. Morphospecies associated with the use of multiple sediment types (hard substratum, coral stand and rubble) ranged between 30.4 and $73.3 \%$ of total observations. Characteristic substrata and morphospecies images for each observed assemblage are presented (Fig. 7).
In the case of the Shannon biodiversity index, percentage cover of sand and gravel had the strongest association $(\mathrm{p}<0.001)$ to lower biodiversity indices (Table 3). Sites classified as containing cobbles, exposed bedrock and pebbles had significantly higher biodiversity $(\mathrm{p}<0.001)$. Number of patches $(\mathrm{p}<$ 0.001) and patch cohesion, an index indicative of greater connectivity (full model: $\mathrm{p}<0.001$, sonar-only model: $\mathrm{p}<0.05$ ), also significantly increased biodiversity, while metrics indicative of large sandy areas (e.g. proportion of like adjacencies) were associated with a decrease in biodiversity (both models: $\mathrm{p}<0.001)$. Percentage cover of corals, and a few associated indices indicative of larger, more closely located patches (e.g. aggregation index [both mod- 
Table 3. Selected environmental variables for the most parsimonious models (with and without including fine-scale imagery-derived information) for the Shannon diversity index $\left(H^{\prime}\right) . \alpha=$ class metrics, $\beta=$ landscape metrics, $\gamma=$ sidescan sonar, $\delta=$ multibeam sonar, $\varepsilon=$ ROV imagery-derived variables. ${ }^{* * *} \mathrm{p}<0.001,{ }^{* *} \mathrm{p}<0.01,{ }^{*} \mathrm{p}<0.05,{ }^{\prime} \mathrm{p}<0.1$

\begin{tabular}{|c|c|c|c|c|}
\hline & $\begin{array}{l}\text { Sonar }- \\
\text { Shannon diversity index }\end{array}$ & Coefficient & $\begin{array}{l}\text { Imagery and sonar }- \\
\text { Shannon diversity index }\end{array}$ & Coefficient \\
\hline $\begin{array}{l}\text { Explanatory } \\
\text { variables }\end{array}$ & $\begin{array}{l}\alpha \text { Aggregation index coral }(75 \mathrm{~m}) \\
\alpha \text { Proportion of like adjacencies sand }(30 \mathrm{~m}) \\
\alpha \text { Proportion of like adjacencies coral }(30 \mathrm{~m}) \\
\gamma \text { Mean backscatter }(30) \\
\alpha \text { Patch cohesion index hard }(75 \mathrm{~m}) \\
\delta \text { Aspect } \\
\alpha \text { Mean shape index mixed }(75 \mathrm{~m}) \\
\alpha \text { Effective mesh size bedrock }(30 \mathrm{~m}) \\
\alpha \text { Effective mesh size coral }(75 \mathrm{~m}) \\
\beta \text { Patch cohesion index (75 m) } \\
\alpha \text { Mean perimeter area ratio hard }(75 \mathrm{~m}) \\
\beta \text { Number of patches }(30 \mathrm{~m}) \\
\alpha \text { Minimum patch core area rubble }(75 \mathrm{~m}) \\
\alpha \text { Landscape shape index sand }(30 \mathrm{~m}) \\
\alpha \text { Mean patch area sand }(75 \mathrm{~m}) \\
\gamma \text { Mean backscatter }(75 \mathrm{~m}) \\
\alpha \text { Minimum patch area coral }(75 \mathrm{~m}) \\
\alpha \text { Proportion of like adjacencies sand }(75 \mathrm{~m}) \\
\alpha \text { Minimum patch core area mixed }(30 \mathrm{~m}) \\
\beta \text { Mean core area index }(30 \mathrm{~m}) \\
\alpha \text { Number of patches sand }(75 \mathrm{~m}) \\
\alpha \text { Mean patch area bedrock }(75 \mathrm{~m}) \\
\beta \text { Division index ( } 75 \mathrm{~m}) \\
\delta \text { Bathymetric position index (coarse) } \\
\alpha \text { Maximum perimeter area ratio sand }(30 \mathrm{~m}) \\
\alpha \text { Patch cohesion index mixed }(30 \mathrm{~m}) \\
\alpha \text { Mean perimeter area ratio hard }(30 \mathrm{~m}) \\
\gamma \text { Variance backscatter }(75 \mathrm{~m})\end{array}$ & $\begin{array}{l}0.003^{* * *} \\
-0.456^{* * *} \\
0.188^{* * *} \\
<0.001^{* * *} \\
-0.188^{*} \\
\text { NA } \\
-0.193^{* *} \\
0.000^{* *} \\
0.039^{* *} \\
0.271^{*} \\
-0.076^{*} \\
0.012^{* * *} \\
0.003^{*} \\
-0.044^{*} \\
<0.001^{* *} \\
-0.001^{* * *} \\
0.002^{*} \\
-0.433^{*} \\
<0.001^{*} \\
0.918^{* *} \\
0.003^{*} \\
<0.001^{*} \\
-0.191^{*} \\
0.012^{*} \\
0.012^{*} \\
-0.136 \\
0.036^{*} \\
<0.001^{*}\end{array}$ & $\begin{array}{l}\varepsilon \text { Percentage cover sand } \\
\varepsilon \text { Sand - cobbles (factor) } \\
\alpha \text { Aggregation index coral }(75 \mathrm{~m}) \\
\varepsilon \text { Percentage cover gravel } \\
\varepsilon \text { Rock - sand (factor) } \\
\varepsilon \text { Rock (factor) } \\
\varepsilon \text { (Percentage cover rubble) }{ }^{\wedge} 2 \\
\varepsilon \text { Cobbles - sand (factor) } \\
\alpha \text { Mean patch area sand }(75 \mathrm{~m}) \\
\beta \text { Patch cohesion index }(75 \mathrm{~m}) \\
\beta \text { Patch richness }(75 \mathrm{~m}) \\
\alpha \text { Proportion of like adjacencies sand }(30 \mathrm{~m}) \\
\varepsilon \text { Percentage cover rubble } \\
\alpha \text { Minimum patch area coral }(75 \mathrm{~m}) \\
\varepsilon \text { Pebbles (factor) } \\
\varepsilon \text { Percentage cover coral } \\
\varepsilon \text { Rubble (factor) } \\
\alpha \text { Maximum perimeter area ratio sand }(75 \mathrm{~m}) \\
\alpha \text { Mean perimeter area ratio hard }(30 \mathrm{~m}) \\
\beta \text { Mean shape index (30 m) } \\
\alpha \text { Minimum patch core area rubble }(75 \mathrm{~m}) \\
\alpha \text { Proportion of like adjacencies coral }(30 \mathrm{~m}) \\
\delta \text { Slope }\end{array}$ & $\begin{array}{r}-0.454^{* * *} \\
0.668^{* * *} \\
0.003^{* * *} \\
-0.455^{* * *} \\
0.927^{* * *} \\
0.950^{* * *} \\
-1.712^{* * *} \\
0.634^{* * *} \\
<0.001^{* *} \\
0.237^{* * *} \\
-0.102^{* *} \\
-0.263^{* *} \\
0.011^{*} \\
0.001^{* *} \\
0.169^{* *} \\
0.300^{* *} \\
0.121^{* *} \\
0.014^{*} \\
0.026^{*} \\
0.091^{*} \\
0.002^{\text {. }} \\
0.088 \\
0.004^{*}\end{array}$ \\
\hline $\begin{array}{l}\text { Adjusted } \mathrm{R}^{2} \\
\text { F-value } \\
\text { p-value }\end{array}$ & $\begin{array}{l}40.6 \% \\
25.6, d f=34,1187 \\
<0.001\end{array}$ & & $\begin{array}{l}63.8 \% \\
94.54, \text { df }=23,1198 \\
<0.001\end{array}$ & \\
\hline
\end{tabular}

els: $\mathrm{p}<0.001$ ], portion of like adjacencies [sonar-only model: $\mathrm{p}<0.05$ ], mean core area index [sonar-only model: $\mathrm{p}<0.01$ ] and effective mesh size [sonar-only model: $\mathrm{p}<0.01]$ ), were also associated with increased biodiversity. Second-order relationships to percentage cover of rubble were also significant $(\mathrm{p}<$ 0.001 ), indicating that they can increase biodiversity when present in intermediate quantities.

Variation partitioning of the models allowed for the separation of the amount of variation explained by imagery versus sonar-derived environmental variables. When the model considering all environmental parameters was partitioned between imagery and sonar-derived environmental variables, fine-scale characterization of substratum percentage cover obtained from the imagery explained the most variation, contributing to a total of $38.6 \%$ for community composition and $59.0 \%$ for biodiversity (Fig. 8). Of those percentages, 16.4 and $31.0 \%$, respectively, were also explained by the selected class and landscape metrics. However, as the full models explained 45.1 and $63.8 \%$ of the variation in community composition and biodiversity respectively, it is clear that the variation explained by the class and landscape metrics was almost entirely captured by the imageryderived substratum percentage cover. Forward selection of PCNMs resulted in 2 sets of 50 PCNMs, which identified 31.1 and $36.0 \%$ of the variation in the morphospecies matrix and biodiversity index, respectively, as resulting from spatial structuring (see Supplement 7 at www.int-res.com/articles/suppl/ m501p067_supp.pdf). Of these percentages associated with spatial structuring, only $5.9 \%$ (morphospecies composition) and $2.0 \%\left(H^{\prime}\right)$ could not be explained by the environmental variables. This variation could be the result of unmeasured environmental variables or spatial autocorrelation resulting from biological interactions. Gaussian variogram fitting of 

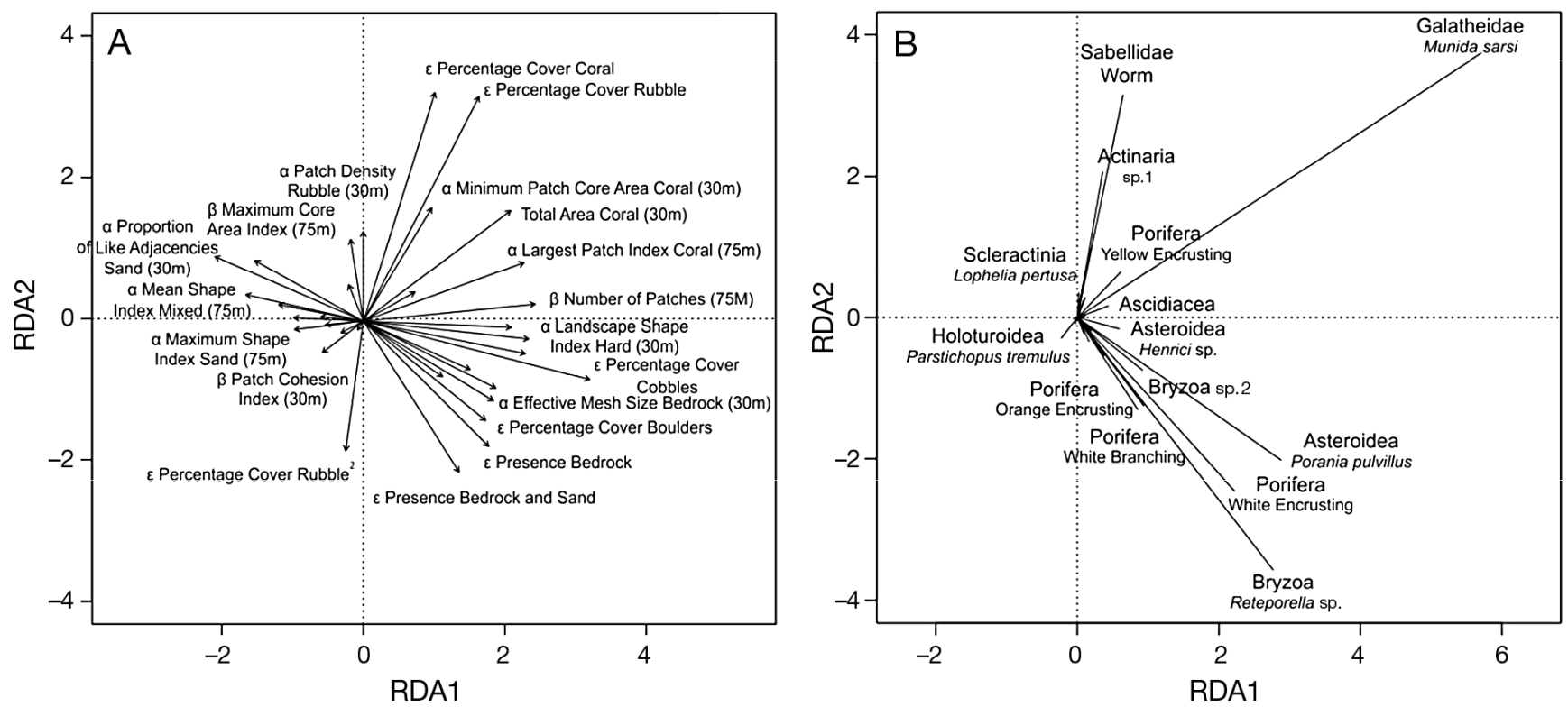

Fig. 5. Redundancy analysis using all significant environmental predictors. For clarity, the triplot is illustrated in 3 separate graphs (A,B and Fig. 6A), and only environmental variables and morphospecies with the strongest effects are labelled. (A) Environmental variables: $\alpha=$ class metrics, $\beta=$ landscape metrics; derived from $\gamma=$ sidescan sonar, $\delta=$ multibeam sonar and $\varepsilon=$ ROV imagery. (B) Morphospecies

site scores for significant canonical axes indicated that ranges in the spatial structure modelled varied between 20 and $50 \mathrm{~m}$.

When model validity was assessed following 100 repetitions, on average $81.1 \%(\mathrm{SD}=2.5 \%$ ) of the 300 images removed were assigned to the same cluster as originally computed using the full model. When only sonar-derived environmental information was used, values of $71.8 \%(\mathrm{SD}=3.9 \%$ ) were obtained.

At the broader scale, transects varied in morphospecies composition, diversity and substratum composition. The $95 \%$ confidence intervals for Transects

Table 4. Total counts based on 1222 images, K-means partitioning cluster association as well as indicator values and significance for the operational taxonomic units observed. Cluster 1: soft sediments, Cluster 2: hard substratum, Cluster 3: coral associated and Cluster 4: occurring on hard substratum, coral stand and rubble. Bold numbers indicate morphospecies presented in Fig. $4 .{ }^{* * *} \mathrm{p}<0.001,{ }^{* *} \mathrm{p}<0.01,{ }^{*} \mathrm{p}<0.05$, $\because \mathrm{p}<0.1$

\begin{tabular}{|c|c|c|c|c|c|c|c|c|c|}
\hline & Morphospecies & Count & Cluster & $\begin{array}{l}\text { Indicator } \\
\text { value }\end{array}$ & & Morphospecies & Count & Cluster & $\begin{array}{c}\text { Indicator } \\
\text { value }\end{array}$ \\
\hline 1 & Parastichopus tremulus & 185 & 1 & 0.06 & 4 & Asterias rubens & 28 & 3 & 0.02 \\
\hline 24 & Caryophyllia sp. 1 & 92 & 1 & 0.03 & 5 & Henricia spp. & 117 & 3 & $0.24^{* * *}$ \\
\hline 34 & Echinus sp. 3 (possibly E. elegans) & 11 & 1 & 0.01 & 7 & Lophelia pertusa & 39 & 3 & $0.53^{* * *}$ \\
\hline 6 & Reteporella sp. & 942 & 2 & $0.72^{* * *}$ & 8 & Sabellidae & 272 & 3 & $0.93^{* * *}$ \\
\hline 14 & Brown cup sponge & 942 & 2 & $0.72^{* * *}$ & 9 & Actinaria sp. 1 & 227 & 3 & $0.72^{* * *}$ \\
\hline 16 & Echinus sp. 2 & 10 & 2 & $0.04^{* *}$ & 10 & Echinus sp. 1 (possibly E. acutus) & 19 & 3 & $0.24^{* * *}$ \\
\hline 18 & Cyclostomatida sp. 1 & 175 & 2 & $0.37^{* * *}$ & 11 & Portunidea sp. 1 & 24 & 3 & $0.08^{* * *}$ \\
\hline 19 & Orange encrusting sponge & 138 & 2 & $0.29^{* * *}$ & 15 & Hippasteria sp.1 & 19 & 3 & $0.06^{* *}$ \\
\hline 20 & White branching sponge & 152 & 2 & $0.43^{* * *}$ & 17 & Translucent tunicate & 96 & 3 & $0.09^{* *}$ \\
\hline 21 & Brown lamellated sponge & 69 & 2 & $0.16^{* * *}$ & 25 & Yellow columnar sponge & 28 & 3 & $0.10^{* * *}$ \\
\hline & White encrusting sponge & 445 & 2 & $0.69^{* * *}$ & 26 & Ophiuroidea & 263 & 3 & $0.16^{* * *}$ \\
\hline & Yellow encrusting sponge & 705 & 2 & $0.54^{* * *}$ & 31 & Hydroidae & 35 & 3 & $0.21^{* * *}$ \\
\hline & Porania pulvillus & 10 & 2 & 0.01 & 2 & Munida sarsi & 2373 & 4 & $0.32^{* * *}$ \\
\hline 29 & Blue encrusting sponge & 38 & 2 & $0.04^{*}$ & 3 & Cidaris cidaris & 59 & 4 & 0.05 \\
\hline & Orange branching sponge & 19 & 2 & $0.05^{* *}$ & 12 & Shrimp sp. 1 & 80 & 4 & 0.03 \\
\hline & Tan columnar sponge & 48 & 2 & $0.10^{* * *}$ & 13 & Orange worm sp. 1 & 233 & 4 & 0.04 \\
\hline & Yellow spherical sponge & 36 & 2 & $0.12^{* * *}$ & 23 & Brown anemone & 13 & 4 & 0.01 \\
\hline 35 & Red encrusting sponge & 60 & 2 & $0.08^{* * *}$ & & & & & \\
\hline
\end{tabular}



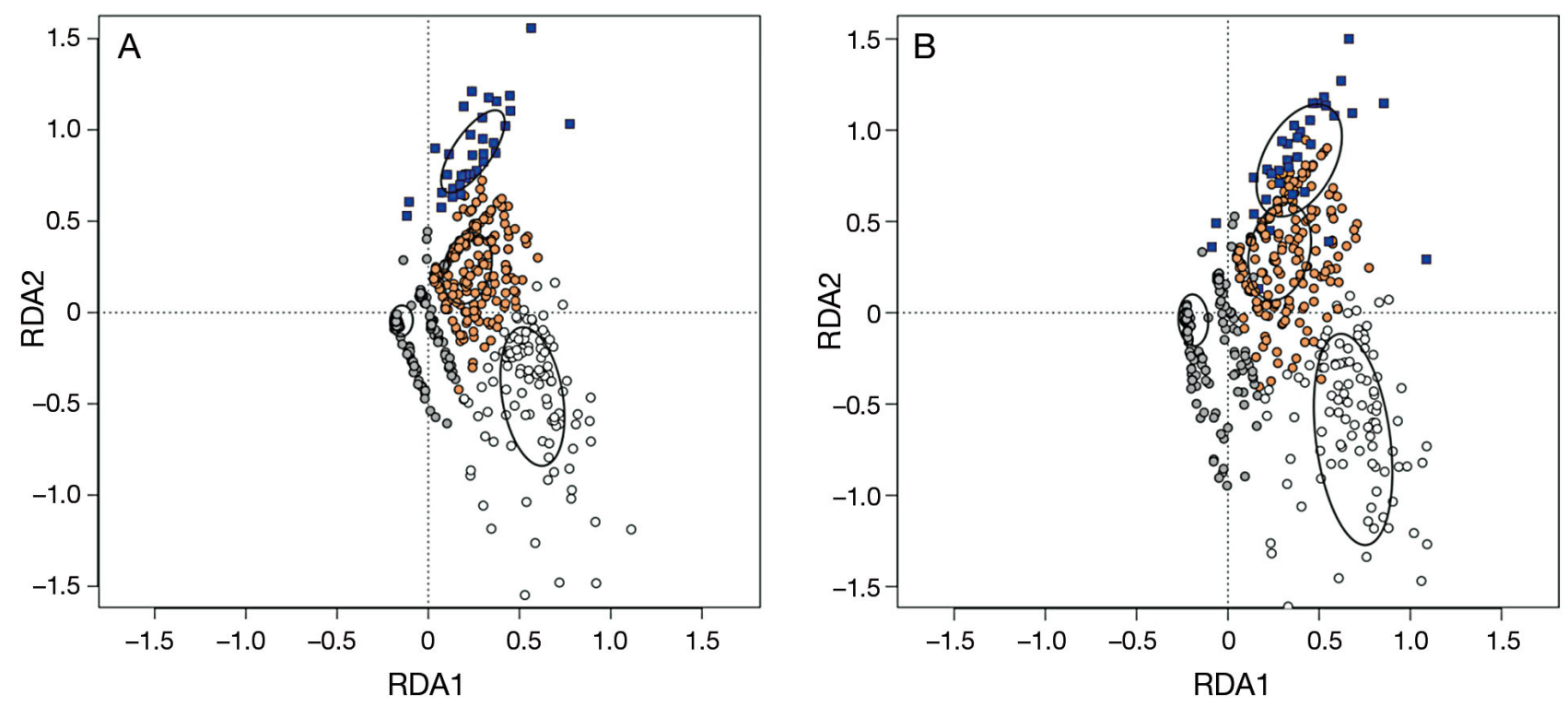

Fig. 6. Position of each image in ordination space (plotted as 'weighted averages of species scores' for the first 2 canonical axes) following redundancy analysis using (A) both imagery and sonar-derived environmental variables, and (B) only sonarderived variables. Sites are colour-coded based on their association to K-means partitioning clusters: soft (grey), mixed (brown) and hard (white) substratum and coral stands (rectangles). Black ellipses indicate the standard deviation surrounding the centroid of each cluster

96 and 97 indicated a significantly lower biodiversity than for the other 3 transects (Fig. 9A). Biodiversity was lowest in soft sediment or rubble-dominated images and highest when cobbles, bedrock or corals were present (Fig. 9B). Significant negative relationships were observed between diversity $\left(R^{2}=-0.167\right.$, $\mathrm{p}<0.001)$ and organism abundance $\left(\mathrm{R}^{2}=-0.159, \mathrm{p}<\right.$ $0.001)$ versus depth. Percentage cover of hard substratum $\left(R^{2}=-0.079, p<0.001\right)$ and coral stands $\left(R^{2}=\right.$ $-0.027, \mathrm{p}<0.001)$ also diminished with depth. Landscape metrics showed similarities across all 5 transects, but class metrics displayed greater variation. At the transect level (200 m buffer), patch sizes averaged $256 \mathrm{~m}^{2}\left(\mathrm{SD}=41 \mathrm{~m}^{2}\right)$, but greater differences were apparent when separated by sediment grain size classes: $9178 \mathrm{~m}^{2}$ (soft), $537 \mathrm{~m}^{2}$ (hard), $160 \mathrm{~m}^{2}$ (mixed), $21 \mathrm{~m}^{2}$ (bedrock), $14 \mathrm{~m}^{2}$ (rubble) and $20 \mathrm{~m}^{2}$ (coral). Soft sediments comprised the largest proportion of the landscape, while exposed bedrock, rubble fields and coral stands were rarely encountered. Exposed bedrock was only recorded along Transects 91 and 104, while large rubble fields were only identified in the sonar maps of Mission 44. Live coral stands of Lophelia pertusa were recorded along Transects 91, 93 and 104. Estimates of the proportion of landscape occupied by each substratum class were highly dependent on the resolution of the observation method. Greater differences were observed when comparing the high resolution imagery to the sediment interpretation maps covering various extents (Table 5). Based on the imagery, soft sediments represented the dominant substratum class in all transects, but Transects 91 and 104 had mixed sediments as their dominant class if sediment interpretation maps were used instead.

\section{DISCUSSION}

This study employed community and landscape analysis approaches traditionally employed in terrestrial settings to examine species-environment relationships based on remotely acquired data of Rockall Bank, NE Atlantic. This represents one of the first applications of these techniques to a deep-sea environment, and the results obtained suggest potential applications for management and conservation requiring fine-scale species distribution and biodiversity information.

\section{Megafaunal distribution and biodiversity}

A strong association between morphospecies distributions and substratum types was observed, yielding 3 distinct assemblages: soft bottom, hard bottom and coral-associated. Although not forming an independent group, the addition of a fourth cluster en- 

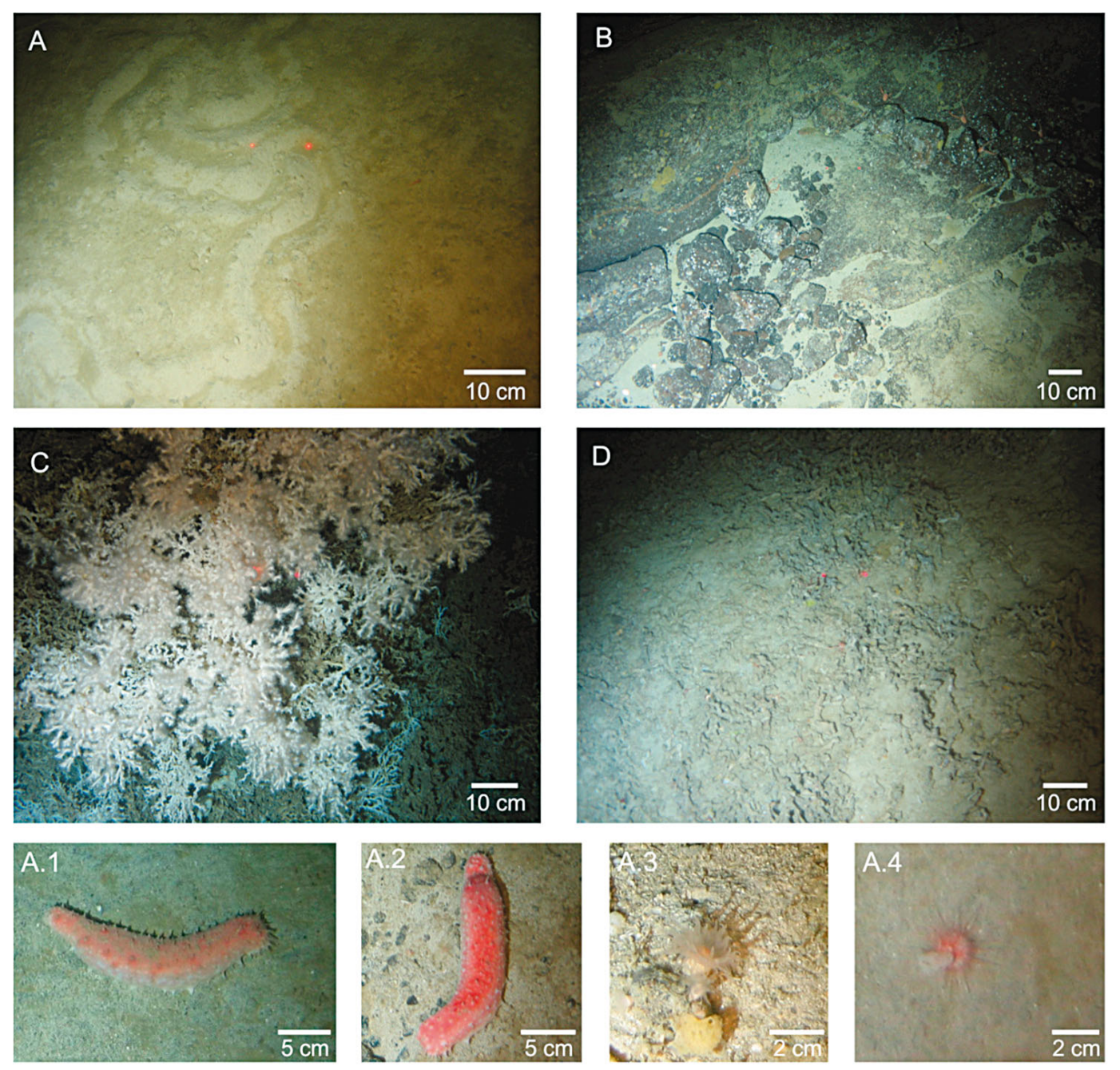

Fig. 7. Characteristic images for substratum classes and associated morphospecies. (A) Soft sediments; (A.1) and (A.2): Parastichopus tremulus, (A.3): Caryophyllia sp. 1, (A.4): Echinus sp. 3 (possibly E. elegans). (B) Hard substratum; (B.1): Reteporella sp., (B.2): Porania pulvillus, (B.3): Echinus sp. 2, (B.4): Porifera (cup sp. 1). (C) Coral stands; (C.1): Porifera (yellow columnar sp. 1), (C.2): Sabellidea sp. 1, (C.3): Actiniaria sp. 1, (C.4): Hippasteria sp. 1. (D) Coral rubble; (D.1): Sipuncula sp. 1, (D.2): Caridea sp. 1, (D.3): Cidaris cidaris, (D.4): Munida sarsi (species also frequently present on hard substratum and live coral stands)
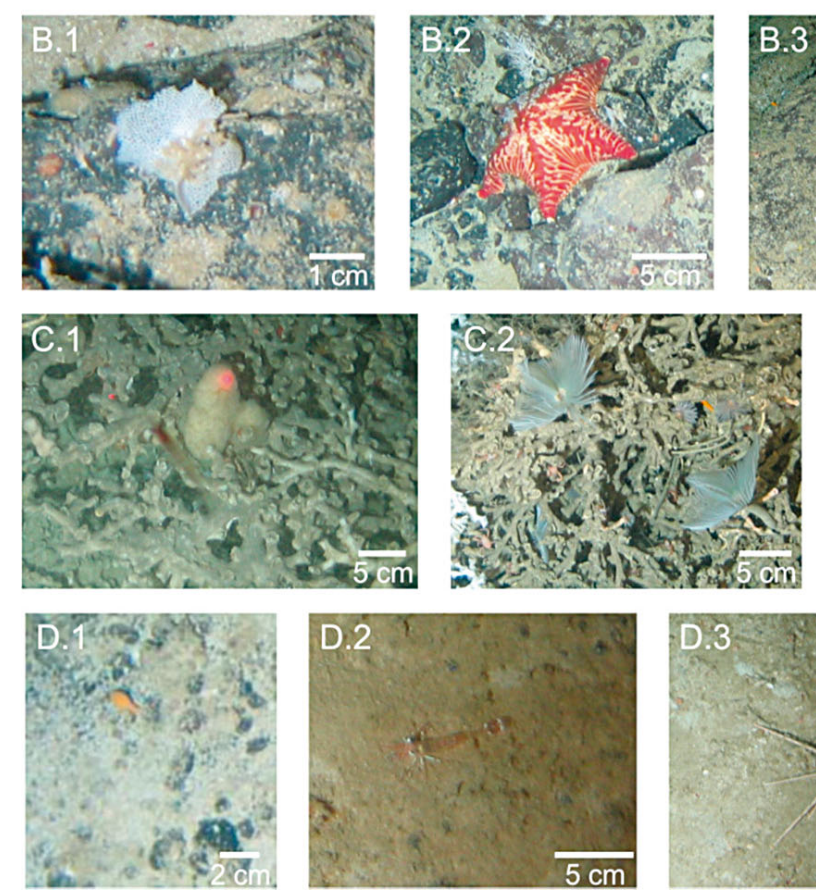
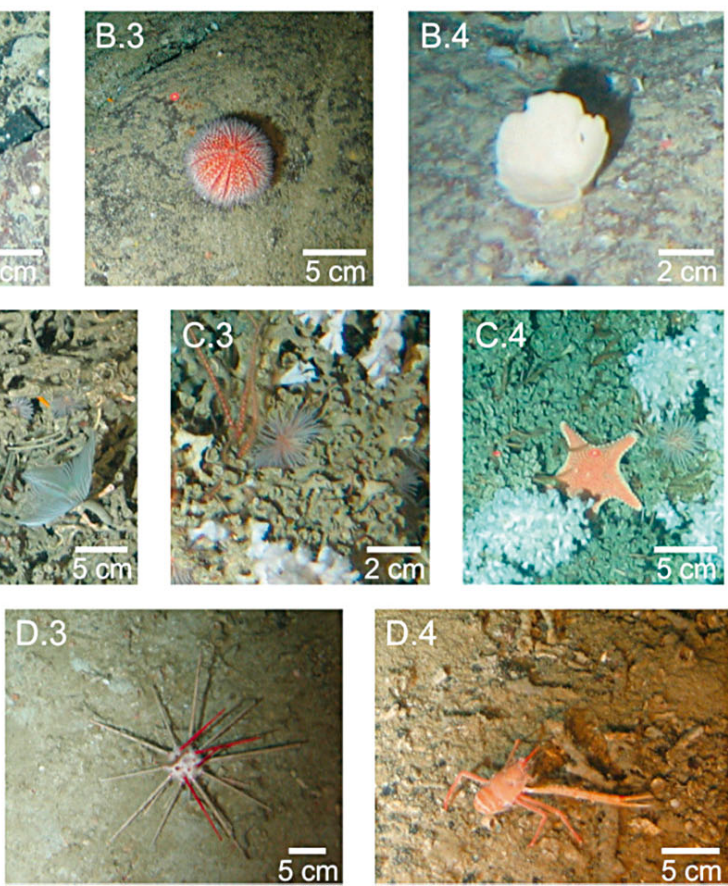

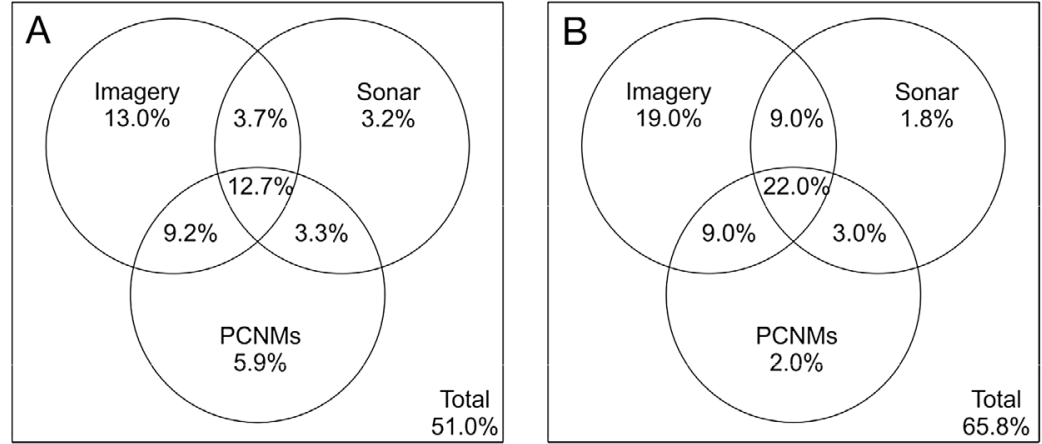

Fig. 8. Venn diagram showing, for the full model, percentages of variation in species composition and biodiversity explained by selected environmental variables extracted from the imagery (\% substratum cover), the sonar maps (backscatter, bathymetry, class and landscape metrics) and the principal coordinates of neighbour matrices (PCNMs). (A) Morphospecies count matrix and (B) Shannon diversity index $\left(H^{\prime}\right)$

abled the separation of morphospecies occurring in multiple substratum classes (hard bottom, coral stands and rubble) from those more closely associated with live coral stands. No morphospecies were significantly associated with soft bottoms, but assemblages dominated by the sea cucumber Parastichopus tremulus have been reported for sandy flat areas by Howell (2010) in Rockall Trough, and BuhlMortensen et al. (2012) in northern Norway. Howell (2010) also reported the concurrent occurrence of the pencil sea urchin Cidaris cidaris, but in our study this species was mostly observed in coral rubble fields. In this study, cup corals Caryophyllia spp. were also observed on isolated cobbles or boulders in soft sedimentdominated areas. The majority of morphospecies in the second assemblage were similar to descriptions of the rocky reef habitat of the central and eastern flanks of Rockall Bank (Howell et al. 2009). Being mostly dominated by encrusting sponge colonies as well as bryozoan species (Cyclostomatida and Reteporella sp.), taxonomic identification was not possible without sample collection and rendered comparisons between studies difficult. As previously reported from other surveys of the region, squat lobsters Munida spp. were commonly observed associated with coarse sediments (gravel and cobbles) (Howell et al. 2009, Howell 2010) as well as on live coral stands and rubble (JNCC 2010a). Finally, sabellid worms and unidentified morphospecies of Actiniaria and Ophiuroidea were repeatedly observed in high densities on live coral stands. Association of suspension feeders (i.e. actiniarians, hydroids, hexactinellids and demosponges as well as crinoids and brisingiids) with Lophelia pertusa has been described for the Franken Mound area on western Rockall Bank (Wienberg et al. 2008) and the nearby, though deeper Rockall Trough (Masson et al.
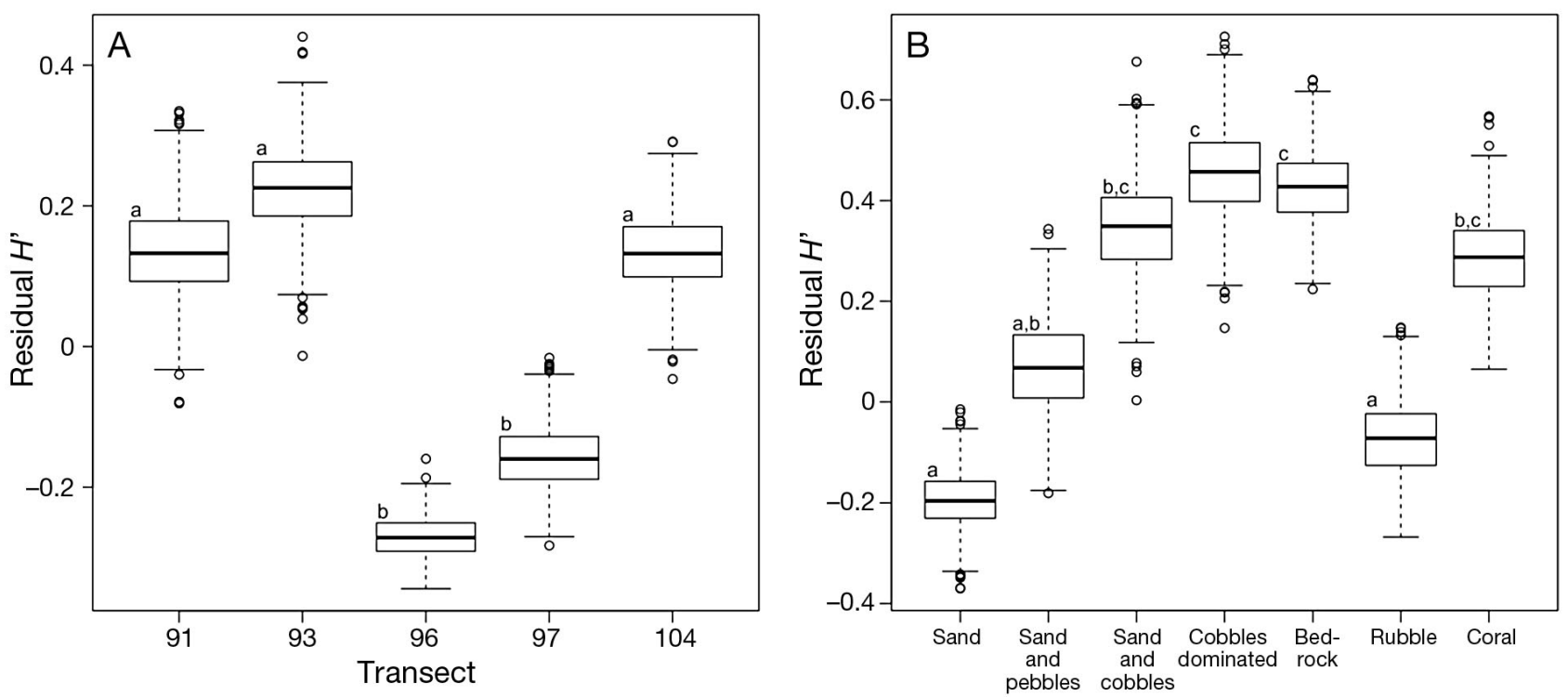

Fig. 9. Difference in residuals between (A) the 5 imagery transects and (B) the seabed facies, after filtering out the spatial structure of the Shannon diversity indices $\left(H^{\prime}\right)$ using significant principal coordinates of neighbour matrices. A bootstrapping procedure was used to standardize sample length. The box shows the median (thick line) as well as the first (lower edge) and third (upper edge) quartiles while the whiskers show the minimum and maximum value excluding any outliers which are illustrated as circles. Letters indicate factors which are not significantly different based on $95 \%$ confidence intervals 


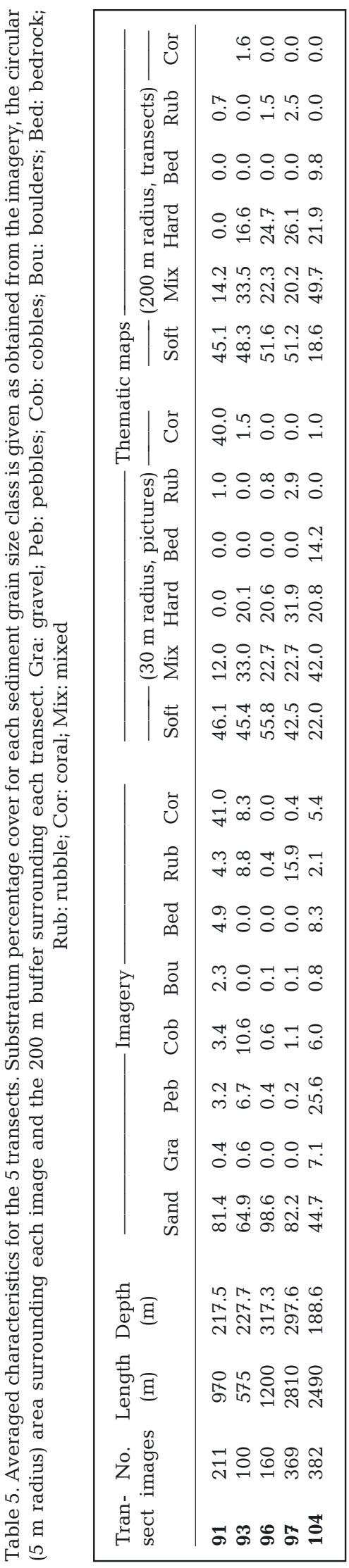

2003). The distribution of similar habitats occupied by many of the same species has been reported for the nearby Hatton Bank (Roberts et al. 2008).

The assemblages observed in this study showed similarities to others described in areas characterized by iceberg reworking of the seabed (Gutt et al. 1996, Gutt \& Piepenburg 2003, Jones et al. 2007a). During the Quaternary Period, the majority of the western and southern flanks of Rockall Bank were left covered in scours averaging 2 to $2.3 \mathrm{~km}$ in length, ranging between 50 and $200 \mathrm{~m}$ in width and up to $8 \mathrm{~m}$ in depth (Sacchetti et al. 2012). As found in other areas of the northwest European continental margin (Freiwald et al. 1999, Wheeler et al. 2007), iceberg debris provided hard ground for cold-water coral colonies to establish. Association of coral colonies with hard substratum originating from iceberg activity has also been observed on the continental margin off Nova Scotia and Newfoundland in the northwest Atlantic (Edinger et al. 2011). Fine-scale distinctions in morphospecies assemblages between the coarser and finer sediments dominating, respectively, the edges and centre sections of iceberg ploughmarks have been reported for other NE Atlantic areas such as Hatton Basin (JNCC 2012), the Wyville Thomson Ridge (JNCC 2010b) and northwest of Shetland (Bett 2001). However, studies in areas of active iceberg formation (Arctic and Antarctic) have shown that the observed patterns in benthic species assemblages and biodiversity are highly dependent on the time elapsed since iceberg disturbance, particularly with respect to slow growing organisms (e.g. sponges and corals) whose presence can affect distributions of associated species (Gutt et al. 1996, Gutt \& Piepenburg 2003). Higher diversity on ploughmark edges dominated by hard sediments has also been reported for the Fimbul ice shelf region, Antarctica, and dominance of bryozoans and encrusting sponge colonies was mostly observed in less disturbed areas (Jones et al. 2007a). At broader spatial scales, when higher diversity is observed in areas of medium iceberg activity levels, it often results from the coexistence of various stages of succession and recovery (Jones et al. 2007b, Teixidó et al. 2007). In the case of Rockall Bank, this high diversity is more likely the result of a spatial dependence of distinct species assemblages on substratum type which varies over fine spatial scales.

Much variation in species-depth relationships occurs at local scales. However, over regional scales, reductions in faunal densities and biomass attributed to a diminishing organic matter supply, and unimodal responses in diversity have frequently been reported 
(Rex et al. 2006). In the current study, the depth range encountered was relatively small $(\sim 100 \mathrm{~m})$, and showed strong collinearity with other environmental variables. For example, higher number of coral colonies and presence of exposed bedrock were observed along the shallower transect, while the deeper transects located at the northern end of the study area were characterized by large expenses of coral rubble fields (likely resulting from previous trawling activities). Those deeper transects had the lowest Shannon diversity index. Cold-water coral stands increase habitat complexity by providing 3-dimensional structures to which fishing activities such as trawling can cause damage (Fosså et al. 2002). As many species are associated with cold-water corals, their destruction is expected to impact composition and diversity of benthic fauna (Roberts \& Hirshfield 2004, Henry \& Roberts 2007). Our study indicated that coral rubble fields did not appear to be exploited by specific morphospecies assemblages, and megabenthic diversity was generally reduced. This contrasts with results obtained by Roberts et al. (2008), who found high diversity of epifauna associated with areas of naturally occurring coral rubble on Hatton Bank. Although images where coral stands were present did not have a significantly higher biodiversity than images dominated by cobbles or bedrock, corals did harbour a specific morphospecies assemblage whose positive influence on diversity was visible at the transect level. Much of the diversity associated with cobbles or bedrock substrata was composed by hard-to-distinguish small encrusting sponge colonies, while large fish aggregations were seen surrounding coral patches but were not included in this analysis.

\section{Landscape approach and environmental variables}

The importance of different environmental variables depended on whether multivariate morphospecies distributions or a diversity index were considered. In both cases, environmental variables with the highest resolution $(\sim 1 \mathrm{~cm})$, such as substratum percentage cover as obtained from imagery were most useful in explaining the variation observed. The use of landscape metrics explained $24.7 \%$ of the variation in morphospecies distribution - values similar to those reported by Teixidó et al. (2007) using similar analyses. Using canonical correspondence analysis to examine structural patterns (characterized by landscape metrics) of successional stages of iceberg disturbance and their effects on an Antarctic benthic community, they found that the 2 first axes explained
$11 \%$ of the observed variation. In our study, although sonar backscatter maps were available at high resolutions ( $0.5 \times 0.5 \mathrm{~m}$ pixel size), the presence of small, single-coral colonies or isolated boulders which were observed within pictures could not be identified in the backscatter. However, their presence within areas of homogeneous soft sediment did affect megafaunal composition. In this environment, these small seafloor features may represent 'keystone structures' (Tews et al. 2004) whose importance could only be captured through ROV imagery. This difference in resolution caused estimates of substratum percentage cover to vary more between acquisition methods than between the different spatial extents considered for the sediment interpretation maps. Hence, in this highly heterogeneous setting, the sole availability of high resolution acoustic surveys (even if covering larger extent) would result in a 35 to $45 \%$ decrease in the amount of biological variation that could otherwise be explained by $\mathrm{cm}$-scale substratum type information. Similarly, the classification of substratum types that was achieved visually provided additional information that is not yet achievable via automated seabed classification of backscatter data. The accuracy of the sediment class assigned is also likely to be higher when based on photographs.

High-resolution sidescan sonar was effective in mapping seafloor heterogeneity resulting from iceberg reworking, and highlighting a similar spatial pattern in megafaunal distribution indicative of spatial induced dependence. Indeed, the ranges identified by variogram fitting ( 20 to $50 \mathrm{~m}$ ) were consistent with iceberg ploughmark widths and patch sizes observed over the larger transect extents $(200 \mathrm{~m}$ buffer). Taking into account this seafloor heterogeneity by examining the surroundings of each image collected using class and landscape metrics resulted in an additional 12 to $17 \%$ of variation explained over the use of only sediment interpretation maps and bathymetry-derived information as proxies for morphospecies assemblages or biodiversity.

The comparatively low resolution $(20 \times 20 \mathrm{~m}$ pixel size), small bathymetric gradient $(\sim 100 \mathrm{~m})$, limited extent considered and absence of topographic features may explain why other bathymetry-derived variables showed poor predictive abilities. However, in other seafloor regions where sediment characteristics do not exhibit the high spatial heterogeneity observed in this study, and where geomorphology shows greater complexity, bathymetric parameters such as slope, curvature and BPI may reveal significant broad-scale patterns in species assemblages (Jones \& Brewer 2012). 
The majority of the metrics selected when morphospecies distributions were considered described patch area and shape, whereas metrics describing areas of greater spatial heterogeneity, such as aggregation metrics, were selected more often when describing variation in biodiversity. In northern Norway, diversity increased in areas of mixed sediment (Buhl-Mortensen et al. 2012). In our study, this increase in diversity resulted from very fine-scale partitioning of the seabed based on sediment hardness. This fine-scale partitioning could be described by substratum percentage cover analysis of the digital stills, but was often lost in the sediment interpretation of the backscatter, yielding a transition zone of mixed sediment class with higher biodiversity, but of insufficient resolution to describe morphospecies assemblages. Effects of patch edges and transition zones on species composition and abundance have also been frequently documented in terrestrial systems, showing positive, negative and neutral relationships (Ries et al. 2004). However, this important concept of landscape ecology has very rarely been examined in marine benthic ecosystems (but see Zajac et al. 2003 for macrobenthos and Anderson et al. 2009 for deep-water demersal fishes). Landscape metrics will only provide valuable information if the spatial patterns they describe can be linked to specific ecological mechanisms, and the development of marine-specific metrics will be required (Wedding et al. 2011). Three-dimensional metrics taking into account the structure of the overlying water masses affecting bentho-pelagic linkages would be one area of potential research. Experimental manipulation of landscape characteristics would also be required to establish links between landscape spatial patterns and specific ecological processes.

\section{CONCLUSION}

Our study showed that for the Rockall Bank area, a strong association exists between morphospecies distribution and sediment characteristics resulting from past iceberg activity. The identified relationships were stronger when fine-scale $(<1 \mathrm{~m})$ imageryderived sediment percentage cover information was available. However, taking into account the surrounding $(30 \mathrm{~m}$ and $75 \mathrm{~m})$ spatial context in which sediment patches were located, using class and landscape metrics nearly doubled the amount of variation in morphospecies composition and biodiversity that could be explained when compared to the use of sediment interpretation maps and bathymetry alone. As the inclusion of this approach does not require that additional time be spent collecting data, it shows potential for increasing our understanding of the links between environmental structure and ecological processes, and may become a useful concomitant step for informing management decisions.

Although we currently do not have the possibility to describe large extents of seafloor to $<1 \mathrm{~m}$ scale resolution levels, the scale ( 20 to $50 \mathrm{~m}$ ) of the ecological process described in this study clearly indicates that most ship-based surveys, which for the depth considered are often processed to pixels sizes of 20 to $50 \mathrm{~m}$ in resolution, would be inadequate to capture the variation observed. For example, the European Nature Information System (EUNIS) classification (Connor et al. 2004) describes the western flank of the Rockall Bank area as mixed sediments separated by depth zones (deep circalittoral and upper slope). Although accurate for the spatial extent and resolution considered, finer scale studies are still required to understand how much of the biological complexity might be underrepresented, and inform conservation measures - particularly those aimed at specific species such as cold-water corals.

Acknowledgements. We thank the captain, crew, technicians and scientific party of the RRS 'James Cook' cruise JC 060. We also acknowledge the following funding sources: Marine Environmental Mapping Programme (MAREMAP; Natural Environment Research Council), HERMIONE (EU FP7 project, Contract number 226354), Joint Nature Conservation Committee (JNCC), the Lenfest Ocean Programme (PEW Foundation), COmplex Deep-sea Environments: Mapping habitat heterogeneity As Proxy for biodiversity (CODEMAP; ERC Starting Grant no. 258482). K.R. is supported by funding from CODEMAP and a Postgraduate Scholarship (PGSD3-408364-2011) from the Natural Sciences and Engineering Research Council (NSERC-CRSNG) of Canada.

\section{LITERATURE CITED}

Anderson TJ, Syms C, Roberts DA, Howard DF (2009) Multiscale fish-habitat associations and the use of habitat surrogates to predict the organisation and abundance of deep-water fish assemblages. J Exp Mar Biol Ecol 379: $34-42$

Bett BJ (2001) UK Atlantic margin environmental survey: introduction and overview of bathyal benthic ecology. Cont Shelf Res 21:917-956

Borcard D, Legendre P (2002) All-scale spatial analysis of ecological data by means of principal coordinates of neighbour matrices. Ecol Model 153:51-68

Borcard D, Gillet F, Legendre P (2011) Numerical ecology with R. Springer, New York, NY

Brown CJ, Sameoto JA, Smith SJ (2012) Multiple methods, maps, and management applications: purpose made seafloor maps in support of ocean management. J Sea Res 72:1-13 
Buhl-Mortensen L, Buhl-Mortensen P, Dolan M, Dannheim J, Bellec V, Holte B (2012) Habitat complexity and bottom fauna composition at different scales on the continental shelf and slope of northern Norway. Hydrobiologia 685:191-219

Clarke KR, Warwick RM (2001) Change in marine communities: an approach to statistical analysis and interpretation, 2nd edn. PRIMER-E, Plymouth

> Commito JA, Rusignuolo BR (2000) Structural complexity in mussel beds: the fractal geometry of surface topography. J Exp Mar Biol Ecol 255:133-152

> Compton TJ, Bowden DA, Roland Pitcher C, Hewitt JE, Ellis N (2013) Biophysical patterns in benthic assemblage composition across contrasting continental margins off New Zealand. J Biogeogr 40:75-89

Connor DW, Allen JH, Golding N, Howell KL, Lieberknecht LM, Northen KO, Reker JB (2004) Marine habitat classification for Britain and Ireland, Version 04.05. Joint Nature Conservation Committee, Peterborough. www. jncc.gov.uk/MarineHabitatClassification

> Dimitriadou E, Dolni ar S, Weingessel A (2002) An examination of indexes for determining the number of clusters in binary data sets. Psychometrika 67:137-159

> Dray S, Legendre P, Peres-Neto PR (2006) Spatial modelling: a comprehensive framework for principal coordinate analysis of neighbour matrices (PCNM). Ecol Model 196: 483-493

> Dray S, Pélissier R, Couteron P, Fortin MJ and others (2012) Community ecology in the age of multivariate multiscale spatial analysis. Ecol Monogr 82:257-275

Dufrêne M, Legendre P (1997) Species assemblages and indicator species: the need for a flexible asymmetrical approach. Ecol Monogr 67:345-366

Edinger EN, Sherwood OA, Piper DJW, Wareham VE, Baker KD, Gilkinson KD, Scott DB (2011) Geological features supporting deep-sea coral habitat in Atlantic Canada. Cont Shelf Res 31:S69-S84

> Fosså JH, Mortensen PB, Furevik DM (2002) The deepwater coral Lophelia pertusa in Norwegian waters: distribution and fishery impacts. Hydrobiologia 471:1-12

> Freiwald A, Wilson JB, Henrich R (1999) Grounding Pleistocene icebergs shape recent deep-water coral reefs. Sediment Geol 125:1-8

Garrabou J, Riera J, Zabala M (1998) Landscape pattern indices applied to Mediterranean subtidal rocky benthic communities. Landscape Ecol 13:225-247

Grober-Dunsmore R, Frazer T, Lindberg W, Beets J (2007) Reef fish and habitat relationships in a Caribbean seascape: the importance of reef context. Coral Reefs 26: 201-216

> Gutt J, Piepenburg D (2003) Scale-dependent impact on diversity of Antarctic benthos caused by grounding of icebergs. Mar Ecol Prog Ser 253:77-83

Gutt J, Starmans A, Dieckmann G (1996) Impact of iceberg scouring on polar benthic habitats. Mar Ecol Prog Ser 137:311-316

Hartigan JA, Wong MA (1979) Algorithm AS 136: a K-means clustering algorithm. J R Stat Soc Ser C Appl Stat 28: 100-108

> Henry LA, Roberts JM (2007) Biodiversity and ecological composition of macrobenthos on cold-water coral mounds and adjacent off-mound habitat in the bathyal Porcupine Seabight, NE Atlantic. Deep-Sea Res I 54: 654-672

Hewitt J, Thrush S, Legendre P, Funnell G, Ellis J, Morrison
M (2004) Mapping of marine soft-sediment communities: integrated sampling for ecological interpretation. Ecol Appl 14:1203-1216

Hewitt JE, Thrush SF, Halliday J, Duffy C (2005) The importance of small-scale habitat structure for maintaining beta diversity. Ecology 86:1619-1626

> Howell KL (2010) A benthic classification system to aid in the implementation of marine protected area networks in the deep/high seas of the NE Atlantic. Biol Conserv 143: 1041-1056

Howell KL, Davies JS (2010) Deep-sea species image catalogue. Marine Biology and Ecology Research Centre, Marine Institute at the University of Plymouth. www. marlin.ac.uk/deep-sea-species-image-catalogue/

Howell KL, Davies JS, Jacobs C, Narayanaswamy BE (2009) Broadscale survey of the habitats of Rockall Bank and mapping of Annex I 'reef' habitat. Joint Nature Conservation Committee, Peterborough

> Howell KL, Holt R, Endrino IP, Stewart H (2011) When the species is also a habitat: comparing the predictively modelled distributions of Lophelia pertusa and the reef habitat it forms. Biol Conserv 144:2656-2665

> Huvenne VAI, Blondel P, Henriet JP (2002) Textural analyses of sidescan sonar imagery from two mound provinces in the Porcupine Seabight. Mar Geol 189:323-341

IOC IHO and BODC (2003) GEBCO digital atlas, centenary edn. Published on CD-ROM on behalf of the Intergovernmental Oceanographic Commission and the International Hydrographic Organization as part of the General Bathymetric Chart of the Oceans, British Oceanographic Data Centre, Liverpool

Jackson EL, Attrill MJ, Jones MB (2006) Habitat characteristics and spatial arrangement affecting the diversity of fish and decapod assemblages of seagrass (Zostera marina) beds around the coast of Jersey (English Channel). Estuar Coast Shelf Sci 68:421-432

Jenness J (2012a) DEM surface tools v. 2.1.305. Jenness Enterprises, Flagstaff, AZ

Jenness J (2012b) Land facet corridor designer v. 1.2.848. Jenness Enterprises, Flagstaff, AZ

Jensen A, Frederiksen R (1992) The fauna associated with the bank-forming deepwater coral Lophelia pertusa (Scleractinaria) on the Faroe shelf. Sarsia 77:53-69

JNCC (2010a) Conservation objectives and advice on operations. Joint Nature Conservation Committee, Peterborough

JNCC (2010b) Offshore special area of conservation: Wyville Thomson Ridge. Joint Nature Conservation Committee, Peterborough

JNCC (2012) Offshore special area of conservation: Hatton Bank. Joint Nature Conservation Committee, Peterborough

> Jones DOB, Brewer ME (2012) Response of megabenthic assemblages to different scales of habitat heterogeneity on the Mauritanian slope. Deep-Sea Res I 67:98-110

> Jones D, Bett B, Tyler P (2007a) Depth-related changes to density, diversity and structure of benthic megafaunal assemblages in the Fimbul ice shelf region, Weddell Sea, Antarctica. Polar Biol 30:1579-1592

Jones DOB, Bett BJ, Tyler PA (2007b) Depth-related changes in the Arctic epibenthic megafaunal assemblages of Kangerdlugssuaq, East Greenland. Mar Biol Res 3:191-204

Jumars PA (1976) Deep-sea species diversity: does it have a characteristic scale? J Mar Res 34:217-246 
Kaandorp JA (1999) Morphological analysis of growth forms of branching marine sessile organisms along environmental gradients. Mar Biol 134:295-306

Klitgaard AB (1995) The fauna associated with outer shelf and upper slope sponges (Porifera, Demospongiae) at the Faroe Islands, northeastern Atlantic. Sarsia 80:1-22

Legendre P (1993) Spatial autocorrelation: trouble or new paradigm? Ecology 74:1659-1673

Legendre P, Legendre L (1998) Numerical ecology. Elsevier Science, Amsterdam

Levin SA (1992) The problem of pattern and scale in ecology: the Robert H MacArthur Award Lecture. Ecology 73:1943-1967

Levin LA, Sibuet M (2012) Understanding continental margin biodiversity: a new imperative. Annu Rev Mar Sci 4: 79-112

> Levin L, Etter R, Rex M, Gooday A and others (2001) Environmental influences on regional deep-sea species diversity. Annu Rev Ecol Syst 32:51-93

$>$ Lucieer VL (2008) Object oriented classification of sidescan sonar data for mapping benthic marine habitats. Int $\mathrm{J}$ Remote Sens 29:905-921

> Masson DG, Bett BJ, Billett DSM, Jacobs CL, Wheeler AJ, Wynn RB (2003) The origin of deep-water, coral-topped mounds in the northern Rockall Trough, Northeast Atlantic. Mar Geol 194:159-180

McClain CR, Barry JP (2010) Habitat heterogeneity, disturbance, and productivity work in concert to regulate biodiversity in deep submarine canyons. Ecology 91: 964-976

McGarigal K, Cushman SA, Ene E (2012) FRAGSTATS (4.x): spatial pattern analysis program for categorical and continuous maps. University of Massachusetts, Amherst, MA

Mellin C, Parrott L, Andrefouet S, Bradshaw CJA, MacNeil MA, Caley MJ (2012) Multi-scale marine biodiversity patterns inferred efficiently from habitat image processing. Ecol Appl 22:792-803

> Monk J, Ierodiaconou D, Bellgrove A, Harvey E, Laurenson L (2011) Remotely sensed hydroacoustics and observation data for predicting fish habitat suitability. Cont Shelf Res 31:S17-S27

> Peng J, Wang Y, Zhang Y, Wu J, Li W, Li Y (2010) Evaluating the effectiveness of landscape metrics in quantifying spatial patterns. Ecol Indic 10:217-223

Peres-Neto PR, Legendre P, Dray S, Borcard D (2006) Variation partitioning of species data matrices: estimation and comparison of fractions. Ecology 87:2614-2625

> Pickett STA, Cadenasso ML (1995) Landscape ecology: spatial heterogeneity in ecological systems. Science 269: 331-334

> Pittman SJ, McAlpine CA, Pittman KM (2004) Linking fish and prawns to their environment: a hierarchical landscape approach. Mar Ecol Prog Ser 283:233-254

Przeslawski R, Currie DR, Sorokin SJ, Ward TM, Althaus F, Williams A (2011) Utility of a spatial habitat classification system as a surrogate of marine benthic community structure for the Australian margin. ICES J Mar Sci 68: 1954-1962

R Development Core Team (2011) R: a language and environment for statistical computing. R Foundation for Statistical Computing, Vienna

- Rex MA, Etter RJ, Morris JS, Crouse J and others (2006) Global bathymetric patterns of standing stock and body size in the deep-sea benthos. Mar Ecol Prog Ser 317:1-8 Ries L, Fletcher RJ, Battin J, Sisk TD (2004) Ecological responses to habitat edges: mechanisms, models, and variability explained. Annu Rev Ecol Evol Syst 35: 491-522

Roberts DG (1971) New geophysical evidence on the origins of the Rockall Plateau and Trough. Deep-Sea Res Oceanogr Abstr 18:353-360

Roberts DG (1975) Sediment distribution on the Rockall Bank, Rockall Plateau. Mar Geol 19:239-257

Roberts S, Hirshfield M (2004) Deep-sea corals: out of sight, but no longer out of mind. Front Ecol Environ 2:123-130

Roberts JM, Henry LA, Long D, Hartley JP (2008) Coldwater coral reef frameworks, megafaunal communities and evidence for coral carbonate mounds on the Hatton Bank, north east Atlantic. Facies 54:297-316

> Rogers AD (1999) The biology of Lophelia pertusa (Linnaeus 1758) and other deep-water reef-forming corals and impacts from human activities. Int Rev Hydrobiol 84: 315-406

> Roy K, Jablonski D, Valentine JW (1996) Higher taxa in biodiversity studies: patterns from eastern Pacific marine molluscs. Philos Trans R Soc Lond B Biol Sci 351: 1605-1613

Sacchetti F, Benetti S, Ó Cofaigh C, Georgiopoulou A (2012) Geophysical evidence of deep-keeled icebergs on the Rockall Bank, Northeast Atlantic Ocean. Geomorphology 159-160:63-72

Sanders HL (1968) Marine benthic diversity: a comparative study. Am Nat 102:243-282

Schlacher TA, Williams A, Althaus F, Schlacher-Hoenlinger MA (2010) High-resolution seabed imagery as a tool for biodiversity conservation planning on continental margins. Mar Ecol 31:200-221

Schoening T, Bergmann M, Ontrup J, Taylor J and others (2012) Semi-automated image analysis for the assessment of megafaunal densities at the Arctic deep-sea observatory HAUSGARTEN. PLoS ONE 7:e38179

> Sellanes J, Neira C, Quiroga E, Teixido N (2010) Diversity patterns along and across the Chilean margin: a continental slope encompassing oxygen gradients and methane seep benthic habitats. Mar Ecol 31:111-124

> Shannon CE (1948) A mathematical theory of communications. Bell Syst Tech J 27:379-423

> Soltwedel T, Jaeckisch N, Ritter N, Hasemann C, Bergmann M, Klages M (2009) Bathymetric patterns of megafaunal assemblages from the Arctic deep-sea observatory HAUSGARTEN. Deep-Sea Res I 56:1856-1872

- Teixidó N, Garrabou J, Arntz WE (2002) Spatial pattern quantification of Antarctic benthic communities using landscape indices. Mar Ecol Prog Ser 242:1-14

> Teixidó N, Garrabou J, Gutt J, Arntz W (2007) Iceberg disturbance and successional spatial patterns: the case of the shelf Antarctic benthic communities. Ecosystems 10: $143-158$

Tews J, Brose U, Grimm V, Tielbörger K, Wichmann MC, Schwager M, Jeltsch F (2004) Animal species diversity driven by habitat heterogeneity/diversity: the importance of keystone structures. J Biogeogr 31:79-92

Thomson CW (1874) The depths of the sea. MacMillan \& Co, London

Thrush SF, Halliday J, Hewitt JE, Lohrer AM (2008) The effects of habitat loss, fragmentation, and community homogenization on resilience in estuaries. Ecol Appl 18: $12-21$

Turner MG, Gardner RH (eds) (1991) Quantitative methods in landscape ecology: the analysis and interpretation of 
landscape heterogeneity. Springer, New York, NY

Verfaillie E, Degraer S, Schelfaut K, Willems W, Van Lancker V (2009) A protocol for classifying ecologically relevant marine zones, a statistical approach. Estuar Coast Shelf Sci 83:175-185

Vetter EW, Dayton PK (1999) Organic enrichment by macrophyte detritus, and abundance patterns of megafaunal populations in submarine canyons. Mar Ecol Prog Ser 186:137-148

> Vetter EW, Smith CR, De Leo FC (2010) Hawaiian hotspots: enhanced megafaunal abundance and diversity in submarine canyons on the oceanic islands of Hawaii. Mar Ecol 31:183-199

Wedding L, Lepczyk C, Pittman S, Friedlander A, Jorgensen S (2011) Quantifying seascape structure: extending terrestrial spatial pattern metrics to the marine realm. Mar Ecol Prog Ser 427:219-232

Wentworth CK (1922) A scale of grade and class terms for clastic sediments. J Geol 30:377-392

> Wheeler AJ, Beyer A, Freiwald A, de Haas H and others (2007) Morphology and environment of cold-water coral carbonate mounds on the NW European margin. Int J Earth Sci 96:37-56

Wienberg C, Beuck L, Heidkamp S, Hebbeln D, Freiwald A, Pfannkuche O, Monteys X (2008) Franken Mound: facies and biocoenoses on a newly-discovered 'carbonate mound' on the western Rockall Bank, NE Atlantic. Facies $54: 1-24$

Editorial responsibility: Paul Snelgrove, St. John's, Newfoundland and Labrador, Canada
Williams CB (1964) Patterns in the balance of nature and related problems in quantitative ecology. Academic Press, New York, NY

Williams A, Althaus F, Dunstan PK, Poore GCB, Bax NJ, Kloser RJ, McEnnulty FR (2010) Scales of habitat heterogeneity and megabenthos biodiversity on an extensive Australian continental margin (100-1100 m depths). Mar Ecol 31:222-236

> Wilson JB (1979a) The distribution of the coral Lophelia pertusa (L.) [L. prolifera (Pallas)] in the north-east Atlantic. J Mar Biol Assoc UK 59:149-164

> Wilson JB (1979b) 'Patch' development of the deep-water coral Lophelia pertusa (L.) on Rockall Bank. J Mar Biol Assoc UK 59:165-177

Wilson JB, Desmond JM (1986) Shelf break faunas on the eastern margin of the Rockall Trough and Faeroe-Shetland Channel. Proc R Soc Edinb (Biol) 88:315-316

- Wilson MFJ, O'Connell B, Brown C, Guinan JC, Grehan AJ (2007) Multiscale terrain analysis of multibeam bathymetry data for habitat mapping on the continental slope. Mar Geod 30:3-35

Zajac R (2008) Challenges in marine, soft-sediment benthoscape ecology. Landscape Ecol 23:7-18

Zajac RN, Lewis RS, Poppe LJ, Twichell DC, Vozarik J, DiGiacomo-Cohen ML (2003) Responses of infaunal populations to benthoscape structure and the potential importance of transition zones. Limnol Oceanogr 48: 829-842

Submitted: January 21, 2013; Accepted: December 2, 2013 Proofs received from author(s): February 18, 2014 